Maurer School of Law: Indiana University

Digital Repository @ Maurer Law

1970

\title{
Of Justice Delayed and Justice Denied: The Welfare Prior Hearing Cases
}

Robert M. O'Neil

Indiana University School of Law - Bloomington

Follow this and additional works at: https://www.repository.law.indiana.edu/facpub

Part of the Administrative Law Commons, and the Constitutional Law Commons

\section{Recommended Citation}

O'Neil, Robert M., "Of Justice Delayed and Justice Denied: The Welfare Prior Hearing Cases" (1970). Articles by Maurer Faculty. 2184.

https://www.repository.law.indiana.edu/facpub/2184

This Article is brought to you for free and open access by the Faculty Scholarship at Digital Repository @ Maurer Law. It has been accepted for inclusion in Articles by Maurer Faculty by an authorized administrator of Digital Repository @ Maurer Law. For more information, please contactrvaughan@indiana.edu. 


\section{OF JUSTICE DELAYED AND JUSTICE}

\section{DENIED: THE WELFARE PRIOR}

\section{HEARING CASES}

Two decades ago, Mr. Justice Frankfurter deemed essential to due process of law "the right to be heard before being condemned to suffer grievous loss of any kind, even though it may not involve the stigma and hardships of a criminal conviction." This broad precept is unexceptionable. Yet its application has been far from uniform. On the very day it was announced, the Court upheld the dismissal without any formal hearing of a federal civil servant suspected of disloyalty on the basis of personal and political affiliations. ${ }^{2}$ In other instances of demial or withdrawal of government benefits-where "grievous loss" is surely incurred-the availability of a hearing has been a matter of much doubt. ${ }^{3}$

The historical development of the constitutional right to a hearing is full of discontinuities, lacunae, and contradictions. Where deprivation of life or liberty is threatened, there has never been any

Robert M. O'Neil is Professor of Law, University of California at Berkeley.

This article has benefited from helpful comments by Professor Hans A. Linde and Peter Sitkin, Esq.-R. M. O'N.

1 Joint Anti-Fascist Refugee Comm. v. McGrath, 341 U.S. 123, 168 (1951) (concurring opinion).

2 Bailey v. Richardson, 341 U.S. 918 (1951) (equally divided Court).

${ }^{3}$ See generally Davis, The Requirement of a Trial-Type Hearing, $70 \mathrm{HARv}$. L. REv. 193 (1956). 
question about the right to be heard before sanctions are imposed.4 Where tangible property is to be taken (directly or indirectly) the opportunity for adversary process has long been recognized. When less tangible interests are at stake, however, the precedents form a curious patchwork. Nearly forty years ago, the Suprenie Court held without dissent that a certified public accountant had a constitutional right to a hearing before his application for admission to practice before the Tax Court could be rejected. ${ }^{6}$ For a decade now, the lower courts have uniformly held that a student at a state college or university $^{7}$ (and occasionally at a private institution) ${ }^{s}$ is entitled to a full and formal hearing before being expelled or suspended for a long period. Yet as recently as 1965 Professor Charles Reich observed that "in the case of a decision removing a family from public housing, or a decision denying aid to families with dependent children, generally the matter is finally determined at some level within the appropriate agency, after investigation by the agency, and with comparatively informal procedures, if any, available to the persons affected." In the sensitive realm of public employment-where only a fraction of all workers enjoy civil service or tenure protection-a constitutional right to be heard before being discharged has never been generally recognized by the courts. ${ }^{10}$ Thus the formality of procedures found even in the regulatory and licensing sectors are notably absent from the administration of many government benefit programs. $^{11}$

4 E.g., In re Oliver, 333 U.S. 257 (1948).

5 E.g., Londoner v. Denver, 210 U.S. 373 (1908).

6 Goldsmith v. Board of Tax Appeals, 270 U.S. 117 (1926).

7 Dixon v. Alabama State Bd. of Educ., 294 F.2d 150 (5th Cir. 1961).

8 See Coleman v. Wagner College, 429 F.2d 1120 (2d Cir. 1970).

${ }^{9}$ Reich, Individual Rights and Social Welfare: The Emerging Legal Issues, 74 YALE L.J. 1245, 1252 (1965).

10 The situation today is substantially as described by Professor Davis over a decade ago. See 1 Davis, Administratrve Latw Treatise 463-73 (1958). The one possible exception is the very recent decision in Olson v. Regents, $301 \mathrm{~F}$. Supp. 1356 (D. Minn. 1969). Most of the scholarly writing on the constitutional aspects of public employment-e.g., Van Alstyne, The Constitutional Rights of Public Employees: A Comment on the Inappropriate Uses of an Old Analogy, 16 U.C.L.A. L. Rev. 751 (1969)-has concerned itself with the substantive protections for free expression and political activity in the public sector and not with procedural safeguards.

11 See Reich, note 9 supra, at 1253. 
The reluctance of the courts to extend procedural protections to government beneficiaries is not easily explained. One theory is that such safeguards are seldom sought or conferred until after judicial recognition of major substantive rights. Yet the protection of the rights of college and university students developed in just the opposite sequence: the courts began by holding that a student was entitled to a formal hearing before being dismissed or expelled ${ }^{12}$ and then proceeded to define the substantive civil liberties a student might claim. ${ }^{13}$

A second possibility is that administrative regulations (or the anticipation of thens) made the quest for constitutional safeguards less urgent. To some extent this has been the case in public housing, where a strong directive from the Department of Housing and Urban Development has largely mooted the due process issue. ${ }^{14}$ But in other contexts, there would have been no protection at all if the courts had awaited agency action; clearly this is so in the student rights area, and more recently with respect to welfare. ${ }^{15}$

A third and more credible theory is that courts have been slow to accord procedural protection to government beneficiaries because the interests affected were so long characterized as "privileges" or gratuities. ${ }^{16}$ In the 1951 case of the summarily discharged civil servant ${ }^{17}$ the court of appeals maintained that a government employee had never been entitled to a "hearing of the quasi-judicial type" because the guarantees of due process applied only when "one is being deprived of something to which he has a right."18 Yet even the untimely persistence and the slow death of the right-privilege distinction $^{19}$ do not adequately explain the lag in developing proce-

12 Dixon v. Alabama State Bd. of Educ., 294 F.2d 150 (5th Cir. 1961); Knight v. State Bd. of Educ., 200 F. Supp. 174 (M.D. Tenn. 1961).

13 See for a thorough review of the evolution of these protections, Wright, The Constitution on the Campus, 22 VAND. L. REv. 1027 (1969).

14 See Thorpe v. Housing Authority, 393 U.S. 268 (1969).

$15 \mathrm{On}$ the cat-and-mouse relationship between the regulation proposed by the Department of Health, Education, and Welfare and the Court decision finally setrling the issue, see text infra, at notes 70-73.

16 See 1 Davis, note 10 supra, at 452-62.

17 Bailey v. Richardson, 341 U.S. 918 (1951).

1s Bailey v. Richardson, 182 F.2d 46, 58 (D.C. Cir. 1950).

10 See generally Van Alstyne, The Denise of the Rigbt-Privilege Distinction in Constitutional Law, 81 Harv. L. Rev. 1439 (1968); Comment, The First Amendment 
dural safeguards for the government beneficiary. The Supreme Court has held for nearly a quarter-century that labeling certain interests as "privileges" does not permit government agencies to dispense or condition them in ways that abridge freedom of speech or discriminate on racial or religious grounds. ${ }^{20}$

Finally, the delay may be attributable simply to the fortuities of test case litigation. In the student rights area, lawyers began by pressing for hearings, in the hope that reinstatement would typically follow even a rudimentary observance of due process. ${ }^{21}$ In the public housing field, litigation of all sorts began much later and concentrated initially on substantive issues. ${ }^{22}$ In the welfare area, attorneys were simply unavailable to bring test suits until the mid1960 's. ${ }^{23}$ And their first concerns were such outrages upon client interests as man-in-the-house, ${ }^{24}$ employable mother, ${ }^{25}$ and one-year waiting period regulations. ${ }^{26}$ Thus the first test suits asking that a client be heard before benefits were terminated simply did not reach

and Public Employees-an Emerging Constitutional Right to Be a Policeman? 37 Geo. Wash. L. Rev. 409 (1968).

20 The series of cases began with Wieman v. Updegraff, 344 U.S. 183 (1952), or perhaps even with Everson v. Bd. of Educ, 330 U. S. 1 (1947).

21 The two earhest cases of the "modern" period of student rights, Dixon v. Alabama State Bd. of Educ., 294 F.2d 150 (5th Cir. 1961); and Knight v. State Bd. of Educ., 200 F. Supp. 174 (M.D. Tenn. 1961), were in fact much more civil rights than student rights cases. They were brought by attorneys for civil rights organizations, seeking a recognition of the compatibility of college attendance at taxsupported institutions and protest against racial segregation.

22 For discussion of efforts to obtain recognition for tenants' substantive rights during the 1960's, see Note, Government Housing Assistance to the Poor, 76 Yale L.J. 508 (1967). There had been a rash of cases during the early 1950's over the constitutionality of a federally required loyalty oath imposed on public housing tenants. See, e.g., Notes, 53 Colum. L. Rev. 1166 (1953); 69 Hakv. L. Rev. 551 (1956). Then the housing field was virtually dormant for almost a decade until substantive rights were reasserted in, e.g., Holmes v. New York City Housing Auth., 398 F.2d 262 (2d Cir. 1968); Holt v. Richmond Redevelopment and Housing Auth., 266 F. Supp. 397 (E.D. Va. 1966).

23 See, e.g., U.S. Department of Health, Education, and Welfare, Neighborhood Legal Services-New Dimensions in the Law (1966); Law and Poverty 1965: Report to the National Conference on Law and Poverty (1965).

24 See King v. Smith, 392 U.S. 309 (1968).

25 See Anderson v. Burson, 300 F. Supp. 401 (N.D. Ga. 1968).

${ }^{26}$ See Shapiro v. Thompson, 394 U.S. 618 (1969). 
the Court until the late 1960 's-long after a series of substantive rights had been tested and vindicated. ${ }^{27}$

Now the decisions of the Supreme Court in Goldberg v. Kelly ${ }^{28}$ and Wheeler $v$. Montgomer $y^{29}$-holding that a welfare recipient is constitutionally entitled to a pretermination hearing-provide the occasion for a re-examination of this whole field of law. After a brief summary of these two cases, I shall proceed to appraise and analyze the decisions-both in terms of what was decided and what was only implied. Against this welfare law background, I shall then consider analogous questions in other government benefit programs. It is necessary to look not only at the beneficiary who is terminated, expelled, or evicted but also at the one whose status is simply not renewed at the end of a term, and even the one whose initial application is denied or rejected. The issues become increasingly difficult and the cases correspondingly fewer throughout this series of questions.

\section{Welfare Benefits and Prior Hearings}

\section{A. THE OPINIONS}

The issues of the right to a prior hearing reached the Supreme Court in parallel cases from New York ${ }^{30}$ and California. ${ }^{31}$ Both states provided fair hearings to beneficiaries who sought them after termination, in accord with the federal statutory requirement for all categorical assistance programs. ${ }^{32}$ In addition, New York and California offered prior notice of the proposed action to any recipient

27 See Comment, The Constitutional Minimum for the Termination of Welfare Benefits: The Need for and Requirements of a Prior Hearing, $68 \mathrm{MrcH}$. L. Rev. 112 (1969), for a review of the cases and the litigation strategy while the issue was pending before the Supreme Court.

28397 U.S. 254 (1970).

29397 U.S. 280 (1970).

30 Kelly v. Wyman, 294 F. Supp. 893 (S.D. N.Y. 1968).

31 Wheeler v. Montgomery, 296 F. Supp. 138 (N.D. Cal. 1968). There were many other suits pending at the time, e.g., McCall v. Shapiro, 292 F. Supp. 268 (D. Conn. 1968); Camerena v. Dep't of Pub. Welfare, 9 Ariz. App. 120 (1969).

3242 U.S.C. $\$ 302$ (a) (4) (old-age assistance or medical assistance for the aged); 42 U.S.C. $\$ 602$ (a) (4) (aid to families with dependent children). The statute specifies neither the time at which the "fair hearing" should be held nor the contents of the hearing. The lavv thus leaves much room for administrative interpretation and implementation. There seems to be some uncertainty about the extent of compliance with this mandate. Comment, note 27 supra. 
threatened with loss of benefits, and at least an informal conference at which arguments could be advanced against termination. But neither state provided a formal adversary or evidentiary hearing before the cutoff took effect.

A majority of the Supreme Court found this procedure constitutionally defective. ${ }^{33}$ The opinion of Mr. Justice Brennan began by observing that welfare benefits "are a matter of statutory entitlement for persons qualified to receive them." 34 While conceding that in certain instances government benefits might be terminated without affording a prior hearing-notably instances in which some emergency was present-the Court found especially compelling and urgent the plight of the welfare beneficiary removed from the rolls: ${ }^{35}$

... termination of aid pending resolution of a controversy over eligibility may deprive an eligible recipient of the very means by which to live while he waits. Since he lacks independent resources, his situation becomes immediately desperate. His need to concentrate upon finding the means for daily subsistence, in turn, adversely affects his ability to seek redress from the welfare bureaucracy.

Thus pretermination hearings were "indispensable" to the needs of the welfare system as well as those of the individual beneficiary: "The same governmental interests that counsel the provision of welfare, counsel as well its uninterrupted provision to those eligible to receive it." 36

Countervailing interests were unpersuasive to the majority. While the prior-hearing requirement might entail some additional expense and administrative inconvenience, the basis of the objections was really only fiscal. However worthy in the abstract, the state's interest in conserving its resources could not outweigh the claims of the destitute beneficiary. And though the state probably could not recoup from judgment-proof recipients any payments erroneously made, "much of the drain on fiscal and administrative resources can be reduced by developing procedures for prompt pre-termination hearings and by skillful use of personnel and facilities." 37 Moreover,

33 Goldberg v. Kelly, 397 U.S. 254 (1970). The decision was 5 to 3, with Chief Justice Burger and Justices Black and Stewart in dissent.

34397 U.S. at 262.

35 Id. at 264.
36 Id. at 265.

37 Id. at 266. 
due process need not include both pre- and post-termination procedures. If the state simply chose to continue payments until a "fair" hearing (consistent with the federal statute) could be held, a single hearing would suffice. ${ }^{38}$

The opinion of the majority concluded by defining the contours of the hearing that must precede termination. It need not take the form of a "judicial or quasi-judicial trial." This hearing had a single purpose: "to produce an initial determination" of the validity of the welfare agency's decision to stop payments in a particular case. Thus "minimal procedural safeguards" would suffice at this stage. These rudiments must, however, include "adequate notice detailing the reasons for a proposed termination, and an effective opportunity to defend by confronting any adverse witnesses and by presenting [the recipient's] own arguments and evidence orally." Only such a personal and formal appearance would suffice to protect the client's constitutional rights; he must be able to "confront and cross examine witnesses relied on by the department." ${ }^{39} \mathrm{He}$ must be allowed representation by retained counsel, although the agency is not obligated to appoint counsel. The decision of the hearing officer must rest "solely on the legal rules and evidence adduced at the hearing." Accordingly, reasons must be given for the decision and references made to the pertinent evidence. Finally, an "impartial decision-maker is essential." While prior involvement of a welfare official in some aspect of the case would not absolutely disqualify him from presiding at the hearing, "he should not have ... participated in making the determination under review." ${ }^{11}$

There were three dissenting opimions. Mr. Justice Stewart noted in a cryptic paragraph that, though he found the issue a close one, he would sustain the constitutionality of the present state practices. ${ }^{42}$ Mr. Justice Black argued at some length that the majority had engaged in unwarranted judicial legislation. He thought the decision was, moreover, without precedent; he could recall no previous instance "in which the person alleged to owe money to another is required by law to continue making payments to a judgment-proof claimant without the benefit of any security or bond to insure that these payments can be recovered if he wins his legal argument." ${ }^{33}$
$38 I d$. at 267 and n. 14.
$41 \mathrm{Id}$. at 271 .
39 Id. at 270.
42 ld. at 285 (dissenting opinion).
40 Id. at 271.
$43 \mathrm{Id}$. at $277-78$ (dissenting opinion). 
Finally, he expressed concern that the decision might hurt indigent persons as a class more than it would help, by causing welfare agencies to tighten the procedure for determining initial eligibility. While assuring that many beneficiaries could not be removed summarily, the decision will "also have insured that many will never get on the rolls, or at least that they will remain destitute during the lengthy proceedings followed to determine initial eligibility."4:

The Chief Justice, in an opinion which Mr. Justice Black joined, expressed two additional concerns: First, he thought the intervention of the Court both unwise and unnecessary because the Department of Health, Education, and Welfare had already proposed a regulation providing most of the protections sought by the beneficiaries in these two cases. ${ }^{45}$ Second, he felt the logic of the majority opinion must carry well beyond its holdings, so the Court could not conscientiously refuse to extend comparable protections to, inter alia, "welfare reductions or denial of increases as opposed to terminations, or decisions concerming initial applications or requests for special assistance." 46 Yet the majority had said nothing about these less drastic changes in status, and this the Chief Justice thought regrettable if not disingenuous.

\section{B. A QUESTION OF TIMING}

The result seems not only sound, but almost inevitable-given the way the issue was framed. Largely through the accident of litigation, the question that really was central and basic-whether a welfare recipient has a constitutional right to a formal, adversary hearing at all-was never before the Court. All the parties assumed that a dispute over continuing eligibility had to be submitted to an evidentiary hearing at some time, the only question being at what stage of the termination process. As far as categorical assistance programs were involved, of course, the issue was narrowed in this way by the "fair hearing" mandate of the Social Security Act. ${ }^{47}$ For all other welfare programs-general assistance payments deriving from state and/or local funds-the availability of a formal hearing was theoretically an open issue. But New York and California law required

4 Id. at 279 (dissenting opinion).

45 Id. at 283 (dissenting opinion).

46 Id. at 285 (dissenting opinion).

4742 U.S.C. $\$ 302$ (a) (4) (old-age assistance or medical assistance for the aged); 42 U.S.C. $\$ 602$ (a) (4) (aid to families with dependent children). 
procedures at least as fair as did the federal statute. If this first case had come from a less enlightened state (Georgia or Mississippi, for example), the Court would not simply have assumed the major premise on the way to announcing the minor one but would have had to face squarely the underlying issue of the right to a hearing as such.

Since only the issue of timing and not that of hearing was before the Court, a different result would have been puzzling. There have been instances, as the majority opinion noted, in which a constitutional right to be heard has been postponed until after the completion of the contested action. ${ }^{48}$ But the circumstances justifying deferral of a conceded right to notice, personal appearance, and confrontation, are highly unusual. 49 There are the classic "emergency" cases-food is about to spoil and must be kept from grocers' shelves; a fraud is about to be perpetrated on unsuspecting securities purchasers; or a professional licensee is continuing to offer his services to trusting clients after having perpetrated malpractice. ${ }^{50}$ In these situations, the reason for acting now and hearing later are incontestable. Moreover, there is usually an adequate remedy after the fact; if the victim of summary action later prevails, he can be made whole or nearly whole through money damages.

Apart from these emergency situations, there seems almost a general presumption that one who is constitutionally entitled to be heard at all should be heard before the change in status occurs. Few cases have dealt specifically with the issue of timing. Occasionally the matter of timing is unimportant to either party; more of ten the dispensing or regulating agency feels its own interests as well as those of the individual are best served by dispatch and voluntarily provides for early resolution of contested claims. ${ }^{51}$

In at least two contexts the Court has clearly recognized the need to assure a hearing in advance of detrimental action. Just before the welfare hearing cases were docketed, a nearly unaninious Court

48 E.g., Ewing v. Mytinger \& Casselberry, Inc., 339 U.S. 594 (1950).

40 See generally 1 Davis, note 10 supra, at 438-44.

50 E.g., Halsey, Stuart \& Co. v. Public Serv. Comm'n, 212 Wis. 184 (1933).

51 There is, of course, a substantial body of law concerning the timing of judicial review of administrative action. In some instances review may be accelerated, in others postponed, and in still others seemingly foreclosed altogether, although the courts are most reluctant to find review completely unavailable. See generally Jaffe, Judicial Control, of Administrative Action 353-76 (1965). 
held Wisconsin's prejudgment wage-garnishment procedure constitutionally deficient because no provision was made for a hearing before the attachment took effect. ${ }^{52}$ The majority opinion stressed the plight of the debtor who, though wholly dependent upon his earnings, lacked any opportunity to contest the garnishment in advance of seizure. The Court concluded: "The result is that a prejudgment garnishment . . . may as a practical matter drive a wageearning family to the wall. Where the taking of one's property is so obvious, it needs no extended argument to conclude that absent notice and a prior hearing ... this pre-judgment garnishment procedure violates the fundamental principles of due process."

The other context in which the timing of the hearing has been litigated-the seizure of allegedly obscene materials-suggests a parallel basis for requiring advance resolution of conflicting claims. The leading case is $A$ Quantity of Copies of Books $\tau$. Kansas. ${ }^{54}$ Over two dissents, the Court held violative of due process a state procedure for seizure and destruction of salacious publications without a prior adversary hearing to determine the central question of obscenity. The statute did provide for a full and fair hearing after the seizure. But the Court found that alternative constitutionally insufficient: "For if seizure of books precedes an adversary determination of their obscenity, there is danger of abridgment of the right of the public in a free society to unobstructed circulation of nonobscene books." "Th The risk of error was substantial. The consequences of error were not only detrimental to basic societal interests but effectively irreversible.

The welfare cases present a claim for prior hearing at least as strong as those just considered-and in any event far stronger than the routine case in which the normal presumption of priority seems to operate. Various special factors militate for pretermination notice and confrontation. First, the New York and California procedures before the Court were about the most benign afforded anywhere in the country, for beneficiaries of general as well as categorical assis-

52 Sniadach v. Family Finance Corp., 395 U.S. 337 (1969).

$53 \mathrm{Id}$. at $341-42$.

54378 U.S. 205 (1964). For recent reaffirmation of this principle in the context of motion pictures, about which the Kansas case left some doubt, see Natali v. Municipal Ct., 309 F. Supp. 192 (N.D. Cal. 1969).

55378 U.S. at 213. 
tance programs. Unlike many states, these two complied fully with federal statutory requirements at the post-termination stage. ${ }^{56}$ Moreover, they did offer beneficiaries threatened with termination a notice which the Court found constitutionally adequate both in time and in form. The constitutional deficiency lay in the content of the hearing. Thus, if hardship could be found in California and New York proceedings, much greater injustice could be expected elsewhere.

Second, a disproportionately high rate of reversals in the few instances where figures are kept ${ }^{57}$ suggests an unusual risk of error inherent in the welfare eligibility process. Various circumstances may make this aspect of administrative action less reliable than others: the heavy caseload burden placed upon often inexperienced caseworkers; the high rate of turnover among caseworkers; the difficulty of garnering accurate information about a population that is frequently anonymous and difficult to reach and with whom communication is severely hampered by suspicion and by barriers of language and culture; and the lack of adequate funds within the welfare budget for detailed record keeping or verification of leads, tips, and accusations about client conduct. ${ }^{58}$ Thus the propensity for error at the factual level is understandably quite high. The danger of wholly erroneous determinations, with attendant serious injustice, is correspondingly great. These circumstances argue strongly for an independent assessment of the factual basis of an adverse administrative action before the action is taken.

Third, the consequences of termination are quite drastic indeed, for reasons hinted at but not fully developed by the Kelly majority. The typical recipient, of course, does not seek welfare until he has already lost the capacity and exhausted the resources to support

50 For the variations in extent of state compliance with federal mandate, see Note, Federal Judicial Review of State Welfare Practices, 67 Colvm. L. Rev. 84, 91-92 (1967).

57 See Bell \& Norvell, Texas Welfare Appeals: The Hidden Right, 46 Tex. L. Rev. 223-24 (1967); Brief for Appellants, Wheeler v. Montgomery, 397 U.S. 280 (1970), at pp. 12-13. The latter source cites eligibility control figures of the California Department of Social Welfare showing that 8 percent of AFDC families had been found on review to have been wrongfully terminated, while in only 1 percent of all cases was aid mistakenly continued.

58 See Note, Eligibility Determinations in Public Assistance: Selected Problems and Proposals for Reform in Pennsylvania, 115 U. PA. L. Rev. 1307, 1326-27 (1967). 
himself. ${ }^{59}$ To remove any doubt, most states require an applicant who comes to the agency in a financially marginal condition to become destitute and dependent before payments can begin. ${ }^{60}$ Characteristic is Connecticut's asset ceiling of $\$ 250$ per welfare family, including even the cash value of life insurance. ${ }^{61}$ Even more stringent is the Illinois rule (for recipients of Aid to Families with Dependent Children) limiting retention of cash or personal property or life insurance to the value of one month's assistance grant. ${ }^{62}$ The mechanism by which self-sufficiency is impaired varies somewhat from state to state, but the effect is uniform. And the result is clear: the family that is erroneously stricken from the welfare rolls may be able to survive on its retained resources (if the maximum amount has in fact been retained), but not for long. The destitute condition that compels the beneficiary to seek welfare in the first place combines with the process of qualifying for payments to make the typical beneficiary totally dependent upon what he receives from month to month from the agency. ${ }^{63}$

Fourth, the post-termination hearing clearly does not afford an adequate alternative. While factual errors can presumably be corrected as well after administrative action as before, the incentive to seek rectification is seriously weakened by the action itself. It is hardly surprising that few beneficiaries do in fact appeal terminations or reductions after the fact. In Illinois, for example, post-termination appeals were filed in a scant one-third of 1 percent of all public assistance cases closed during a sample period several years ago. ${ }^{64}$ Comparable experience in the District of Columbia showed a slightly more frequent resort to the formal hearing (about 1.5 percent), although about half the initial requests were withdrawn after an informal conference. ${ }^{65}$ The few other states where appeal rates have been sampled offer similar evidence. ${ }^{66}$

59 See Briar, Welfare from Below: Recipients' Views of the Public Welfare System, in LAW OF THE POOR 46, 50 (J. ten Broek ed. 1966).

60 Note, Withdrawal of Public Welfare: The Right to a Prior Hearing, 76 YAlE L.J. 1234, 1242 (1967).

61 lbid. 62 Ibid.

${ }^{63}$ See Burrus \& Fessler, Constitutional Due Process Hearing Requirements in the Administration of Public Assistance: The District of Columbia Experience, 16 Axr. U. L. Rev. 199, 215 (1967).

64 Note, note 60 supra, at 1244.

65 Burrus \& Fessler, note 63 supra, at 213.

60 E.g., in Texas, see Bell \& Norvell, note 57 supra, at 223, 233. 
There may be many reasons, no doubt, for the passivity of terminated welfare recipients. Arguably, of course, the administrative decision goes unchallenged in most cases because it is substantially correct. Yet no one who has surveyed the situation accepts this explanation for the great majority of unappealed decisions. The operative causes undoubtedly lie deeper. In some cases, beneficiaries may simply not know they have recourse if they are wrongfully terminated. Far more often, they have the bare information but do not know how to use it. "The point is not whether they were told about these rights," observes Scott Briar (who has sampled welfare client attitudes extensively). "Our observations indicate that many, if not most, of these recipients probably were given this information by the social worker-but rather that the information probably is not particularly meaningful and useful to a person who sees himself as a suppliant, and therefore it may be ignored or soon forgotten." 67 (Briar's survey discovered, for example, appalling misconceptions about the person to whom a complaint should be made in the event of disagreement about disposition of any part of the case.)

Joel Handler and his associates have noted the same phenomenon in more recent surveys of welfare recipients in Wisconsin. Senior administrators argued that the paucity of appeals and requests for hearings reflected the fairness and the accuracy of the systen. But "administrators younger and closer to the field said that there was a great deal of withholding of information from clients, that administration was highly discretionary, and that the administrative appeal system was not working because clients were either unatvare of their rights or were afraid of exercising them."68 Thus, as one commentator recently explained the wide gap between theoretical availability and actual use of post-termination hearings: "The welfare recipient may be illiterate; he may not understand how to obtain a hearing; he may regard welfare as a charity and not realize that it may be asserted as a right; he niay believe that requesting a hearing would damage his interests by angering the social worker; or he may be afraid to attend the hearing." 69 In any case, the bare opportunity to appeal a termination after it has taken effect does not seem always or adequately to protect client interests.

67 Briar, note 59 supra, at 55.

68 Handler \& Hollingsword, Stigma, Privacy, and Other Attitudes of Welfare Recipients, 22 Stan. L. Rev. 1, 18 (1969).

60 Comment, note 27 supra, at 130-31. 
Finally, there is the pendency of the new HEW regulation, which Chief Justice Burger thought more or less mooted the case. The language had been drafted and announced many months before the cases reached the Supreme Court. The new ruling provides that whenever a fair hearing is requested because of termination or suspension of payments, "assistance will be continued during the period of appeal and through the end of the month in which a final decision on the fair hearing is reached."70 At first glance, this regulation would appear to protect recipients' rights even more broadly than the Supreme Court's decision; it requires not merely an evidentiary hearing before payments stop but the statutory fair hearing, containing safeguards not ordered by the Court for the pretermination stage.

The mere pendency of the regulation did not, however, afford a viable alternative to the constitutional recognition of a hearing right. First, there was some doubt whether the regulation would ever have taken effect had the Court not made it almost superfluous. ${ }^{71}$ The new rule was scheduled to go into force July 1, 1969. Implementation was postponed to October 1 of the same year and further postponed to July 1,1970, by which time the Supreme Court would surely have decided the two pending cases. HEW could easily have taken the credit for moving first had that been its desire. ${ }^{72}$ Moreover, the Solicitor General in his amicus curiae brief expressly relied only on the old regulations and even cast doubt upon the wisdom of the proposed new policy of continuing benefits: "[C]ogent policy considerations support the Secretary's judgment that the ... practice [of holding no prior hearing] should be followed where... the State initially decides to terminate or reduce benefits." 73

Even if implementation of the new HEW policy had been assured, a constitutional decision would still have been vital. There are obvious lacunae. The federal rule applies, of course, only to categorical

7034 FED. Reg. 1144 (1969).

71 See Christensen, Of Prior Hearings and Welfare As "New Property," 3 Clearinghouse Rev. 321, 336 (1970).

72 The Department of Housing and Urban Development, by contrast, did issue a comparable regulation in advance of a binding Supreme Court decision. See Thorpe v. Housing Authority, 393 U.S. 268 (1969).

${ }^{73}$ Brief for the United States as Amicus Curiae, Wheeler v. Montgomery, 397 U.S. 280 (1970), at p. 23. 
assistance in which federal funds are used, and has no bearing whatever on state-supported general assistance programs such as New York's home relief, involved in some of the cases of several plaintiffs in the Kelly case. Moreover, there is some doubt about the enforceability of a hearing right that derives solely from a regulation of this kind. To be sure, the Supreme Court took a rather hard line in the application of a parallel HUD regulation dealing with public housing evictions, even insisting that directive be given retroactive effect. ${ }^{74}$ Yet, as one commentator has observed: "Federal welfare regulations are administrative directives addressed solely to state agencies, and do not grant substantive rights to individuals. Thus, under the new federal regulation, there is no right to a prior hearing, and a recipient who bases his claim solely on that regulation may be unable to obtain relief in either a state or federal court."75 Finally, of course, an administrative ruling of this kind-particularly one drafted in the last days of the Democratic administration and greeted with little enthusiasm by Republican successors-is a rather shaky reed to which to bind such fundamental rights. Because it was always subject to modification or even revocation, the administrative directive needed the reinforcement of constitutional doctrine adequately to protect the vital interests of welfare recipients.

Thus the result that the Court reached in this pair of cases seems eminently sound. Further reflection and analysis strengthen the case in favor of a prior hearing. Not only is the general presumption operative in favor of the right to be heard in advance of a serious deprivation, but the governmental interest in postponing the hearing is rather insubstantial. In addition, the interests of the affected individual are unusually strong. So strong, in fact, that one might well say the opportumity to be heard is meaningful only if the hearing occurs while the beneficiary is still receiving subsistence payments.

\section{UNRESOLVED ISSUES}

There is much left unsaid in the welfare hearing cases. Most of the omissions must have been deliberate in view of the explicit and pointed references of the dissenters. Yet they may be troublesome in the future and must therefore be taken into account by anyone

74 Thorpe v. Durham Housing Auth., 393 U.S. 268 (1969).

75 Comment, note 27 supra, at 117. 
seeking to determine the meaning of these decisions for the redefinition of due process.

1. The initial determination of eligibility. The only reference to procedural protections during the initial determination of eligibility for welfare came in the dissent of the Chief Justice. The reference was only a casual suggestion that the majority had raised "intriguing possibilities" about procedural claims at other stages of welfare administration, including the intake decision. ${ }^{76}$ Yet this question obviously lurks nearby. The brief of the Solicitor General implied that a decision to grant a pretermination hearing might logically require comparable treatment before rejecting even a frivolous application. ${ }^{77}$ The joint brief of the claimants, in reply to the United States, vigorously disputed the suggestion on two grounds. First, that settled principles of administrative law recognize "a well founded and established distinction between initial denial and revocation of statutory rights, entitlement or privileges ... which is as valid and recognized in the welfare context as in all others."78 Second, the reply brief argued that "by hypothesis the recipient of aid is far more dependent and vulnerable than the applicant."70

The strategy was sound. For the moment it kept tlie Court's mind off collateral issues. But the argument was not so sound. The issue will surely return before long. One very thoughtful analysis of the intake process argues forcefully that the rejected applicant needs and merits a hearing for the very reasons that support the incumbent beneficiary's claim to pretermination notice and confrontation. ${ }^{80}$ The question is obviously not settled. The implications of Kelly for several types of initial determinations are considered below. ${ }^{81}$

2. Changes in status less drastic than termination. Chief Justice Burger also reminded his colleagues they had not dealt with the procedural interests of the beneficiary whose payments are reduced summarily or who is denied a requested increase because of the caseworker's spot judgment. There may be informal internal ave-

70 Goldberg v. Kelly, 397 U.S. 254, 284-85 (1970) (dissenting opinion).

77 Brief for the United States as Amicus Curiae, Wheeler v. Montgomery, 397 U.S. 280 (1970), at pp. 22-23.

78. Brief in Reply to the United States as Amicus Curiae, Goldberg v. Kelly, 397 U.S. 254 (1970), at p. 6.

79 Id. at n. 5.

80 Note, note 58 supra, at $1327-28$.

81 See text infra, at notes 202-08. 
nues of appeal from such decisions. But the fair hearing assured by federal law does not apply to such interim administrative acts. ${ }^{82}$ Much less is there any guarantee of a formal hearing under state law in the dispensation of general assistance payments. Yet in some cases a sharp reduction in benefit levels, or a refusal to increase payments when the recipient's status changes materially, may affect client interests almost as severely as the complete cessation of payments.

Nor did Kelly deal explicitly with the recurrent problem of temporary suspension rather than final termination of payments. The welfare laws of most states do permit summary suspension of benefits "even where no specific cause for ineligibility has been found." ${ }^{\text {"3s }}$ Hence the case for notice and confrontation may be even stronger here than in the termination situation with which the Court actually dealt, since there at least a formal hearing is available after payments finally cease. Maybe the Court meant to assimilate suspension and termination without quite saying so. The Kelly opinion speaks throughout only of "termination." But the much briefer $W$ beeler opinion characterizes Kelly as holding that a pretermination evidentiary hearing is required "before welfare payments may be discontinued or suspended." ${ }^{\prime 84}$ Although this is the only reference to temporary changes in a beneficiary's status, it may suffice. ${ }^{85}$

3. Beneficiary rights after the bearing. The Kelly decision is quite explicit about what the recipient is entitled to and when. But it fails to take the process one step further. What happens if the pretermination decision is adverse (as it will be in most cases) and the beneficiary appeals? (If in fact an internal appeal channel is proyided, though none appears to be constitutionally required.) Must benefits continue until the appeal has been decided, or may they be terminated as soon as the initial decision is rendered? The HEW regulation is also ambiguous on this point. It provides that benefits must continue through the end of the month "in which the final decision on the fair hearing is reaclied."

There is also an open question about the beneficiary's status during judicial review. In fact, there is even considerable doubt he will be able to litigate his claim at this stage. Mr. Justice Brennan expressly allowed that "a complete record and a comprehensive

8242 U.S.C. $\$ \$ 302$ (a) (4), 602 (a) (4).

83 See Note, note 60 supra, at 1234-35.

84397 U.S. at 282.

85 See Christensen, note 71 supra, at 336-37. 
opinion, which would serve primarily to facilitate judicial review and to guide future decisions, need not be provided at the pretermination stage." ${ }^{86}$ If a court does take the case and reaches the merits, the Supreme Court decision says nothing about the agency's obligation to continue payments until there is a final resolution of the controversy. Of course the great majority of cases will never go beyond the pretermination hearing. ${ }^{87}$ But when the beneficiary does seek court review and the court either lacks power or inclination to issue a status quo order pending decision, the issue left open by Kelly will most surely arise.

4. Right to counsel. Despite its insistence on limiting the holding, it seems doubtful the Court can logically stop by recognizing a right to be represented by retained counsel. By definition, no welfare client can afford a lawyer and must turn to legal aid and other sources of volunteer counsel. A serious equal protection problem may now be presented if welfare agencies permit representation by counsel of beneficiaries fortunate or resourceful enough to obtain the aid of an OEO Legal Services office but fail to make any provision for assignment of counsel for those less fortunate or less resourceful. ${ }^{88}$ Thus, Mr. Justice Black seems correct in assuming that the logic of the decision must require appointment of counsel, else "the right to counsel is a meaningless one since these people are too poor to hire their own advocates." 89

5. The basis of the due process guarantees: property, "entitlement," and other benefits. The cornerstone of the Kelly decision is the conviction that the interest of a welfare beneficiary in not being erroneously or summarily removed from the rolls merits constitutional protection. The basis of that judgment requires some further study. The Constitution provides only that due process must be

86 Goldberg v. Kelly, 397 U.S. 254, 267 (1970).

87 Even the number of requests for pretermination hearings in those jurisdictions where it is available is surprisingly small. See Brief in Reply to the United States as Amicus Curiae, Goldberg v. Kelly, 397 U.S. 254 (1970), at p. 19.

88 Cf. Douglas v. Califorma, 372 U.S. 353 (1963). Ironically, the HEW regulation requires that counsel be provided for all beneficiaries at the "fair hearing" (which must, under that ruling, occur before payments terminate). 34 FED. REG. 1144, 1356, 1359 (1969). Moreover, the Federal Trade Commission has recently announced that attorneys will be provided for persons charged with consumer fraud or other violations by the agency and who cannot afford to retain private counsel. N.Y. Times, Jan. 10, 1970, p. 67, col. 4.

89397 U.S. at 278-79. See also Christensen, note 71 supra, at 339. 
observed in deprivations of life, liberty, and property. Most previous cases upholding claims to be heard-where a government agency planned to proceed summarily-involved actual takings of physical property.90 Even in the 1969 wage garnishment decision, on which the Court relied in Kelly, nearly jurisdictional emphasis was placed upon "the taking of one's property." claims to be heard have most often been rejected because the claimant was held to have no proprietary stake in the dispute. In Bailey v. Richardson, ${ }^{92}$ for example, the court of appeals had refused to order a hearing in the public employment context because "due process of law is not applicable unless one is being deprived of something to which he has a right." 93

These distinctions revive the specter of the long-interred rightprivilege dichotomy. For some years the Supreme Court has deliberately avoided these labels and their irrational effects. ${ }^{94}$ In prior cases involving, for example, social security ${ }^{95}$ and unemployment compensation, ${ }^{96}$ the Court insisted it made no difference whether one called receipt of such benefits a right or a privilege, or whether a property interest could be established. "It is too late in the day," cautioned Mr. Justice Brennan seven years ago in the unemployment compensation case, "to doubt that the liberties of religion and expression may be infringed by the denial of or placing of conditions upon a benefit or privilege." 97 The Court has simply avoided or refused the temptation to classify government benefits in the process of defining and extending safeguards for their enjoyment. ${ }^{98}$

Much in the Kelly opinion is, of course, consistent with this approach. The Court did caution that "the constitutional challenge cannot be answered by an argument that public assistance benefits

90 E.g., Londoner v. Denver, 210 U.S. 373 (1908).

91 Sniadach v. Family Finance Corp., 395 U.S. 337, 342 (1969).

92 182 F.2d 46 (D.C. Cir. 1950), aff'd, 341 U.S. 918 (1951).

93182 F.2d at 58.

94 See generally Van Alstyne, note 19 supra; and Linde, Justice Douglas on Freedom in the Welfare State: Constitutional Rights in the Public Sector, 39 WASH. L. REv. 4 (1964).

95 Flemming v. Nestor, 363 U.S. 603 (1960).

90 Sherbert v. Verner, 374 U.S. 398 (1963).

97 Id. at 404 .

98 See Wieman v. Updegraff, 344 U.S. $18 \dot{3}$ (1952). 
are 'a "privilege" and not a "right." " "99 But this caveat was preceded by the troubling observation that "such benefits are a matter of statutory entitlement for persons qualified to receive them."100 This comment could not have been inadvertent, since it supported a lengthy footnote quoting from Professor Charles Reich's equation of many newer forms of "entitlement" with more traditional proprietary interests. ${ }^{101}$ Thus it seems that the Court now accepts the "new property" characterization of at least some forms of government benefits and is willing to encompass many types of beneficiary claims within the "property" dimension of the Due Process Clause.

The reference to "entitlement" invoked a response to Mr. Justice Black, who chided the Court for failing to specify the proprietary quality of welfare benefits: "lt somewhat strains credulity to say that a government's promise of charity to an individual is property belonging to that individual when government denies that the individual is honestly entitled to receive such payment."102 The majority might well have dismissed this challenge as irrelevant to the issue before it, arguing, as has often been done in the past, that interests in government benefits need not be so classified to merit protection under the Due Process Clause. ${ }^{103}$

The fact that the Court did thus respond and did invoke the language of entitlement to delineate a quasi-property interest seems ominous in two respects. First, the very use of this terminology may indicate that some kinds of government benefits rank higher than others on a still unannounced priority list. Claims to receive them may constitute "entitlement," while claims to other benefits may not be so favored. Second, there is a lurking implication that claims to procedural due process may require a firmer basis than claims of substantive rights. The Court had previously freed welfare recipients of waiting period restrictions ${ }^{104}$ and demeaning income attribution

99 Goldberg v. Kelly, 397 U.S. 254, 262 (1970).

$100 \mathrm{Id}$. at 262. For pre-Kelly comments on the question of statutory entitlement, see Graham, Public Assistance: The Right to Receive; the Obligation to Repay, 43 N.Y.U. L. Rev. 451, 454-75 (1968); Note, Social Welfare-an Emerging Doctrine of Statutory Entitlement, 44 Notre Dame Law. 603 (1969).

101 Reich, note 9 supra, at 1255; Reich, The New Property, 73 Yale L.J. 733 (1964).

102397 U.S. at 275.

103 E.g., Wieman v. Updegraff, 344 U.S. 183 (1952).

104 Shapiro v. Thompson, 394 U.S. 618 (1969). 
rules $^{105}$ without invoking the language of "entitlement." It is of course too early to wonder whether the acceptance of Professor Reich's concept of government benefits may not jeopardize beneficiaries of other sorts whose claims fall less clearly within the category of "entitlement."

This anxiety is heightened by the Court's differentiation of welfare payments from other types of benefits. At first the opinion suggested that "relevant constitutional restraints" apply at least as much to withdrawal of public assistance payments as to "disqualification for unemployment compensation ... or to denial of a tax exemption ... or to discharge from public employment." ${ }^{106}$ But in deciding the issue of the right to a prior welfare hearing, the Court drew sharp distinctions that overshadowed these analogies: "The crucial factor in this context-a factor not present in the case of the blacklisted government contractor, the discharged government employee, the taxpayer denied tax exemption, or virtually anyone else whose governmental largesse is ended-is that termination of aid pending resolution of a controversy over eligibility may deprive an eligible recipient of the very means by which to live while he waits." ${ }^{107}$ Thus emerged a paradox. On the one hand, a suggestion that welfare payments are at least as inuch entitled to protection as other benefits for which procedural safeguards have already been prescribed. On the other hand, a clear implication that other beneficiaries do not merit the new protection being accorded welfare recipients because they have no such unique claim to a prior hearing. The lack of mutuahity is puzzling and confirms the hunch that the Court has begun compiling a rank order or priority list of government benefits. ${ }^{108}$

In the months immediately following the Kelly decision, however, lower federal courts have given the holding a more generous interpretation than its language might support. One federal court of appeals found in Kelly the basis for a public housing tenant's

\footnotetext{
105 King v. Smith, 392 U.S. 309 (1968).

100397 U.S. at 262.

107 Id. at 264.

108 Some doubt is cast upon the primacy of welfare benefits-briefly implied by the Kelly and Wheeler decisions-by the Court's rejection a short time later of welfare recipients' attacks on state maximum grant provisions. Dandridge v. Williams, 397 U.S. 471 (1970). Cf. also Rosado v. Wyman, 397 U.S. 397 (1970), raising other doubts about the status of welfare benefits in the scale of priorities. See for an early comment, May, Supremne Court Approves Maximum Grants: Holds $\$ 402$ (a) (23) Permits Welfare Cuts, 3 Clearinghouse Rev. 321 (1970).
} 
constitutional claim to a pre-eviction hearing, ${ }^{109}$ an issue the $\mathrm{Su}$ preme Court earlier avoided because of a nearly coextensive HUD regulation. ${ }^{110}$ A federal district judge held on the basis of Kelly that a state prisoner may not be committed to punitive segregation for postconviction infractions without written notice of charges and an adversary hearing with representation by counsel. ${ }^{111}$ And in the boldest application to date, a federal district court in Ohio held that an applicant for admission to public housing is now entitled to a prior hearing on the question of his eligibility before the application is rejected: "Since the recent decisions of the Supreme Court [in Kelly and Wheeler] . . . it seems clear . . . that those seeking to be declared eligible for public benefits may not be declared inehgible without the opportunity to have an evidentiary hearing." 112 Thus the question that Kelly clearly did not reach in the welfare context-the right of an applicant to be heard before being rejected-has already been resolved in the applicant's favor in a context the Court would presumably have deemed less conpelling than that in Kelly.

These recent decisions have begun to unfold the broader set of issues, the relevance of Kelly to at least three types of administrative action affecting the status of government beneficiaries: first, the availability of a hearing upon dismissal, discharge, termination or eviction; second, the procedural safeguards surrounding a refusal to renew or continue a relationship at the end of a regular term; third, the rejection of an initial application. Before parsing these issues, however, some sort of general analytical framework is essential. It seems appropriate to begin by identifying more explicitly than is usually done the values and limitations of the adversary hearing.

\section{A Framework for Constitutional Analysis: Government Benefits and Adversary Hearings}

Because of the way the parties narrowed the issues, the Court in Kelly effectively subsumed the basic constitutional ques-

\footnotetext{
109 Escalera v. New York City Housing Auth., 425 F.2d 853 (2d Cir. 1970). For a consistent, pre-Kelly decision, see Ruffin v. Housing Auth., 301 F. Supp. 251 (E.D. La. 1969).

110 Thorpe v. Housing Authority, 393 U.S. 268 (1969).

111 Sostre v. Rockefeller, 312 F. Supp. 863, 871-73 (S.D. N.Y. 1970).

112 Davis v. Toledo Metropolitan Housing Auth., 311 F. Supp. 795, 796-97 (N.D. Ohio 1970).
} 
tion. When and why does a government beneficiary merit an adversary hearing on a disputed claim of eligibility? The Court borrowed a test announced a decade earlier in determining whether a security clearance could be revoked without a hearing. ${ }^{113}$ Under that formula, the governmental interests in taking summary action must be balanced against the interests of the individual in knowing and challenging the basis of an adverse decision. In the security clearance case the balance weighed in the Government's favor. ${ }^{114}$ In Kelly, application of the same formula supported the claims of the individual recipient. ${ }^{115}$ Since that is about all the balancing test offers-and since it mandates no inquiry into the basic functions or values of an adversary hearing-deeper analysis is clearly appropriate.

Several guidelines must be understood at the start. First, I am tallking only about cases in which the dispute or controversy revolves about what Professor Kenneth Davis calls "adjudicative facts." His definition bounds the inquiry: "Adjudicative facts are facts about the parties and their activities, businesses, and properties, usually answering questions of who did what, where, when, how, why, and with what motive or intent; adjudicative facts are roughly the kinds of facts that go to a jury in a jury case." ${ }^{\text {"116 }} \mathrm{I}$ am not here concerned with legislative facts or claims to be heard on determinations of policy or adoption of administrative rules and regulations.

Second, I confine my inquiry to relatively serious administrative actions, actions having substantial consequences for the affected private party. There are easy cases at both ends of the scale, of course. When a public housing tenant is evicted, a state college student expelled, welfare payments terminated, or a government worker discharged, everyone would concede the action is sufficiently serious to merit the concern of a court, and a fortiori of an administrative tribunal. ${ }^{117} \mathrm{~A}$ mild reprimand or admonition, a re-

113 Cafeteria \& Restaurant Workers Union v. McElroy, 367 U.S. 886 (1961).

114 The decision was 5 to 4. The Chief Justice and Justices Black, Brennan, and Douglas felt the case for an adversary hearing compelling despite the Government's conceded security interests.

115397 U.S. at 263-66.

116 Davis, note 3 supra, at 199.

$117 \mathrm{~A}$ working formula has been offered in at least one context, that of university discipline. Judge Doyle of the Western District of Wisconsin-who has probably decided more student reinstatement suits than any other member of the federal bench-has limited his concern to "serious sanctions, such as expulsion or suspension 
quest for information, a change in the timing or manner of distributing benefits-these may be sanctions too inconsequential to warrant the heavy artillery of due process.

The hard cases lie between. A student is suspended for several weeks; the severity of the sanction may depend critically on whether the period is at the start or the end of a semester. A public housing tenant is told he can no longer keep a dog in his apartment; if he simply wants a friendly pet, that is one thing, but it is quite another if he happens to be blind. The welfare recipient is denied an increase in payments; the sanction may be very drastic if the increase is sought to support a new member of the family, but far less so if designed to facilitate a move to more comfortable quarters. And so it goes through the whole range of government benefits. A judgment about the gravity of the case simply cannot be made in the abstract or according to any rigid rule. A careful inquiry must be made into the precise circumstances of eacl case when the sanction giving rise to a demand to be heard is of such an intermediate sort.

Third, I shall not, for the moment, be concerned about the timing of the hearing. Suffice it to say-and this is the essential teaching of Kelly-that a case for a prior hearing differs only in degree and not in kind from the case for being heard at all. The question of the right to an adversary hearing, without regard to time, is anterior in all cases. Once the right to be heard has been established, then the hearing should precede the challenged action unless the agency has strong and constitutionally valid reasons for postponement. In any event, the matter of timing is typically an ancillary question to be resolved separately.

\section{A. INTERESTS AND VALUES SERVED BY AN ADVERSARY HEARING}

Although cases recognizing a right to a hearing are legion, explicit statements of rationale are surprisingly rare. Perhaps the reasons for holding or requiring hearings are so obvious they sel-

for a significant period of time." Stricklin v. Regents, 297 F. Supp. 416, 419 (W.D. Wis. 1969), appeal dismissed, 420 F.2d 1257 (7th Cir. 1970). See also Professor Charles Wright's perceptive discussion of the difficulty of delineating clearly between "severe" and "mild" penalties. Wright, note 13 supra, at 1071. Although the range of available sanctions seems no narrower in other government benefits contexts, the courts do not appear even to have attempted the process of delineation elsewhere. 
dom need reiteration. Yet there are many values served by hearings that are not at all obvious and deserve occasionally to be brought to light. One could not do better than begin with Mr. Justice Frankfurter's eloquent statement: ${ }^{118}$

The heart of the matter is that democracy implies respect for the elementary rights of men, however suspect or unworthy; a democratic government must therefore practice fairness; and fairness can rarely be obtained by secret, one-sided determination of facts decisive of rights.

This comprehensive postulate invites a particularization of components.

1. Accuracy and fairness. At base, only a hearing-probably only an adversary hearing-can prevent or correct errors of fact. Mistakes of identity, distortions or fabrications, faulty memories, bare deceit-these mendacious forces can be checked only when an opportunity is afforded to pose the truth against the falsehood. Chief Justice Warren a decade ago explained the truth-seeking function of an adversary hearing: "Where governnental action seriously injures an individual, and the reasonableness of the action depends on fact findings, the evidence used to prove the Government's case must be disclosed to the individual so that he has an opportunity to show that it is untrue."119 The need for such confrontation is especially important "where the evidence consists of the testimony of individuals whose memory might be faulty or who, in fact, might be perjurers or persons motivated by malice, vindictiveness, intolerance, prejudice or jealousy."120

There is an additional element in the process, explaining the need for personal participation of the affected person: "The parties," Professor Davis pointed out, "know more about the facts concerning themselves and their activities than anyone else is likely to know, and the parties are therefore in an especially good position to rebut or explain evidence that bears upon adjudicative facts." 121 Thus

118 Joint Anti-Fascist Refugee Comm. v. McGrath, 341 U.S. 123, 170 (1951) (concurring opinion).

110 Greene v. McElroy, 360 U.S. 474, 496 (1959).

120 lbid. See also 5 Wigmore, Evidence $\$ 1367$ (3d ed. 1940) (showing evolution and soundness of "the belief that no safeguard for testing the value of human statements is comparable to that furnished by cross-examination").

121 Davis, note 3 supra, at 199. 
mere adjudication is not enough; there must be an opportunity for direct confrontation of accuser by accused if the opportunity to seek the truth is to be meaningful.

If superficially obvious, it is nevertheless worth asking why the administrative process should concern itself so acutely with the quest for truth. Two interests are at stake. First, the credibility of the process and its entitlement to respect-both by persons subject to it and persons whose tax dollars support it-demand that a high value be placed upon accuracy. Nothing so surely shakes public confidence as revelations of unreliability or haphazard judgment in important regulatory or distributive processes. ${ }^{122}$

Second, the capacity of the administrative system to deal fairly and justly with particular individuals who are subject to or dependent upon it also requires a commitment to accuracy and truth. Erroneous decisions are not always unjust. Indeed, occasional errors may improperly favor one beneficiary at little or no cost to others. But most errors are bound to produce injustice, whether by deprivation or by misallocation.

Moreover, the consequences of erroneous judgment may be both tragic and permanent. The student who is wrongfully expelled without a chance to be heard may be effectively deprived of a higher education. If he cannot take one set of exams, the sequence may be so interrupted that he will never return. Or he may be drafted before he has a chance to re-enroll, and may never again be financially able to study even if he survives military service without misfortune. ${ }^{123}$ Similar hazards mandate a hearing prior to seizure and destruction of allegedly obscene materials. Once books have been burned or tapes erased, restitution becomes impossible. Money damages can be paid to the publisher or distributor, of course, if there is a basis for civil liability against the responsible public officials. But as the Supreme Court has pointed out repeatedly in this context, the reading or viewing public can never be made whole after the seizure and destruction. ${ }^{124}$ The risks of irreversible error

122 See Professor Newman's comment: "The public interest in procedure itself ... is . . . to ensure that correct determinacions will be made (and thus only the deserving deprivations be effected), except where some margin of error seems essential to avoid ills that inhere in procedure. . . The problem is to set the margin of tolerable error, given the ills of too much procedure." Newman, The Process of Prescribing "Due Process," 49 CaLIF. L. Rev. 215, 228 (1961).

123 Cf. Murray v. Blatchford, 307 F. Supp. 1038 (D.R.I. 1969).

124 A Quantity of Copies of Books v. Kansas, 378 U.S. 205, 211-13 (1964). 
are thus too great to permit the process to operate without the intervention of an impartial tribunal to decide the issue of obscenity. Much the same is true in the welfare context, as the Court stressed in Kelly. If a beneficiary is wrongfully removed from the rolls, he can of course be restored when the truth comes out. But the effects of even a relatively brief deprivation may be almost irremediable. Deaths seldom result from interruption of payments. ${ }^{125}$ But serious cases of malnutrition and other grave physical harm are well known to welfare workers. ${ }^{126}$ Thus erroneous decisions may indeed create a degree of injustice intolerable in the disbursement of public funds.

There is another sort of injustice-serious damage to reputationthat can be checked only through an adversary hearing. Several courts have recognized this interest in overruling summary agency action that implied disloyalty, incompetence, or bad moral character. ${ }^{127}$ Even if no explicit charge is made against a particular applicant, the very act of rejection may create such a "badge of infamy" when it is widely understood that eligibility follows almost automatically from formal qualifications. ${ }^{128}$ Only through an adversary hearing can the applicant clear.his name of the cloud that unexplained exclusion casts. Thus the Supreme Court held seven years ago that an applicant for admission to the bar was constitutionally entitled to a hearing on adverse ex parte changes that led the Committee on Character and Fitness to exclude him summarily. ${ }^{129}$

125 Elizabeth Wickenden reports the case of a baby who froze to death because its parents, newly arrived in Arlington, Virginia, and completely destitute, were denied welfare because they did not meet the now invalid one-year residence test. See Dorsen, Poverty, Civil Liberties and Civil Rights: $A$ Symposizm, 41 N.Y.U. L. REv. 328, 339 (1966).

128 See, e.g., the description of the interim plight of the very plaintiffs in the Kelly case. Brief for Appellees, Goldberg v. Kelly, 397 U.S. 254 (1970), Appendix A (pp. 75-91).

127 E.g., Slochower v. Bd. of Educ., 350 U.S. 551, 558-59 (1956); Heckler v. Shepard, 243 F. Supp. 841 (D. Idaho 1965); cf. Healy v. James, 311 F. Supp. 1275 (D. Conn. 1970), holding that state college authorities could not summarily reject the application of a campus SDS group for recognition as a student organization. A hearing must be held, inter alia, to determine whether the campus group shares the objectives and supports the tactics of the national organization; the absence of a hearing would leave the perhaps erroneous impression that such correspondence does exist, thus imposing a kind of guilt by association on the local members:

128 See the concurring opinion of Mr. Justice Douglas, in Joint Anti-Fascist Refugee Comm. v. McGrath, 341 U.S. 123, 174 (1951).

120 Willner v. Committee on Character and Fitness, 373 U.S. 96 (1963). The risks of injustice and fundamental concepts of fairness should make clear that the basic 
2. Accountability. Adversary hearings also promote, in several important respects, the accountability of the agency. Only when there is a record and findings based upon evidence and argument can a reviewing court really determine, for example, whether the agency is accurately interpreting and applying the legislative mandate, ${ }^{130}$ whether the action taken by the agency reflects valid and substantial governmental interests, ${ }^{131}$ and whether substantive constitutional interests are being adequately protected. The problem with summary action here is not so much that it necessarily imports error as that it is inevitably ambiguous. Only when the argument and the reasons are spread upon the record can the reviewing court appraise the performance of the agency and its faithfulness to its charge.

Accountability is preserved in quite another important way through adversary hearings. Substantive rights and liberties of government beneficiaries are really only as strong as the procedural safeguards available to vindicate them. ${ }^{132}$ If a state college student can be expelled without a hearing or the giving of any reasons by the administration, there is very little point in saying he has a constitutional right to demonstrate peacefully on the campus. Even if he has cheated on an examination as well as marched quietly against the Vietnam war, there is no assurance that a proper ground of dismissal was invoked rather than an improper ground, unless he can know the charges against him and face his accusers in an adversary setting. The recent dramatic extension of the civil liberties of public housing tenants, government employees, and welfare cli-

need for an adversary hearing is independent of the quest for accuracy. That is, even if complete accuracy could be achieved without a hearing (as it probably can in some phases of many government benefit programs), critical determinations should not be deemed "fair" in the absence of an opportunity to be heard. For only the adversary process accords beneficiaries the dignity and respect to which they are entitled as citizens, regardless of their dependency upon some form of government subvention. The hearing thus serves a psychological need in the administration of benefit programs that may be even more basic to a civilized system of administration than the function of ascertaining the truth. Surely the development of alternative, even completely accurate, methods of truth-seeking would not moot the need for hearings.

130 See generally Professor Jaffe's comments on "the role of judicial review." JAFFE, note 51 supra, at 320-27.

131 E.g., Knight v. State Bd. of Educ., 200 F. Supp. 174, 181 (M.D. Tenn. 1961). 132 Roth v. Board of Regents, 310 F. Supp. 972, 979-80 (W.D. Wis. 1970). 
ents, as well as those of students, would have been largely in vain without the parallel expansion of procedural safeguards. Only by insisting on the right to a hearing can the courts impose the essential measure of agency accountability for the rights and liberties of those to whom benefits are dispensed.

3. Visibility and impartiality. Both the appearance and the reality of objectivity and the absence of bias require that the actions of any tribunal be visible. Commitment to these values in the courts is preserved by making all proceedings public save in the most extraordinary circumstances. ${ }^{133}$ The same public access is neither as feasible nor as effective in keeping administrative agencies honest. Yet the same values are operative, and to ensure them the agency proceedings must be both accessible and visible in ways that only adversary hearings can adequately guarantee. "The validity and moral authority of a conclusion," Mr. Justice Franlfurter observed, "largely depend on the mode by which it was reached. Secrecy is not congenial to truth-seeking and self-righteousness gives too slender an assurance of rightness." No better way than the adversary hearing has been found "for generating the feeling, so important to a popular government, that justice has been done."134

4. Consistency. The adversary hearing also serves the vital function of seeing that the agency establishes and acts in accord with its own precedent as well as within its charter. Consistency and predictability are values of a high order in the administrative process, even if they do not rise to the dignity of stare decisis by which courts are bound. Sunimary action clearly affords no assurance of consistency. Indeed, it invites decisions and actions varying with the pressures and needs of the moment. If the agency must state its reasons, and if the reasons given earlier can be cited in support of parallel results in later parallel cases, a far higher measure of consistency and predictability can be expected.

5. Integrity. I have already suggested some ways in which the adversary hearing promotes the integrity of and respect for the administrative process. But there are two additional dimensions. If the beneficiary is entitled to confront his accusers before the agency can penalize him, the risk of false accusation is significantly

${ }^{133}$ See In re Oliver, 333 U.S. 257, 266-73 (1948).

134 Joint Anti-Fascist Refugee Comm. v. McGrath, 341 U.S. 123, 171-72 (1951) (concurring opinion). 
decreased. The accuser knows that he, along with the agency that acts on the basis of his charges, may be held accountable under cross-examination. At the same time, the beneficiary himself may be less likely to appeal frivolously-either when the sanction is relatively slight or when the basis for agency action is substantially correct-since he too realizes that the adversary hearing will discover the truth. Thus a higher measure of responsibility is imposed upon both accuser and accused by the adversary process and the expectation of a full, formal confrontation.

In summary, the overriding interest of both beneficiary and system in the adversary process is the achievement of accuracy and fairness. The requirement of notice and the opportunity for confrontation combine to deter erroneous agency action and to avert the certainly harmful, sometimes irreversible, consequences of error. Other interests also served by the adversary process are secondary though not unimportant.

\section{B. COUNTERVAILING GOVERNMENTAL INTERESTS}

The one set of governmental interests I have already reviewedemergency conditions demanding prompt action-argue not against hearings as such but only against prior hearings. ${ }^{135}$ In the government benefits context, other types of interests may weigh more generally against the adversary process. These interests, though seldom dispositive, deserve careful consideration.

Perhaps most persuasive is the concern that a formal hearing may destroy collegial, informal relationships, and set at arm's length people who are not truly adversaries. Thus it has been much argued recently that college student discipline is often better handled through informal conferences with the "kindly old dean" than through full-dress adversary hearings; that student personnel officers perform a vital counseling role that may be undermined if not destroyed by recent court decisions; and that a once cooperative relationship between students and administration has now become one of conflict or combat. ${ }^{136}$ Similar arguments have been made occasionally in other contexts-against the formalization of juvenile

135 The cases are discussed in 1 Davis, note 10 stipra, at $\$ 7.08$.

136 E.g., Perkins, The University and Due Process 8 (1967); Glazer, Campus Rights and Responsibilities: $A$ Role for Lawyers, 39 American Schol. 445, 447-51 (1970). 
court proceedings after the Kent ${ }^{137}$ and Gault ${ }^{138}$ decisions, for example, and even in the welfare context, where informal counseling surely constitutes a vital aspect of the caseworker's task..$^{139}$

There are several answers to these concerns. First, of course, not every aspect of the once informal relationship has now been formalized by recognition of the right to a hearing. Informal counseling by the dean's office still reaches vastly more students on most campuses than are ever involved in formal hearings. ${ }^{140}$ Moreover, the formal hearing is mandatory only if the beneficiary himself requests it. On the campus, in the welfare agency, or almost anywhere else (save perhaps in the juvenile court), a preference shared on both sides for continued informal relationships need not be thwarted by the Due Process Clause.

Further, it is far from clear where a hostile relationship does develop that the courts are to blame for creating it. Radical students and punitive deans would be no more congenial in the absence of procedural safeguards, as suggested by experience on private campuses (where constitutional safeguards do not yet apply). ${ }^{141}$ Nor would welfare mothers be any more inclined to accept passively an arbitrary termination or reduction of payments in the absence of a right to be heard and to appeal. Indeed, if anything, the opposite may be the case. Protests against the system and its policies may well be diverted into more constructive channels by creating an opportunity to confront one's accusers and vindicate one's interests in a

137 Kent v. United States, 383 U.S. 541 (1966).

138 In re Gault, 387 U.S. 1 (1967). Note especially in this regard the dissenting opinion of Mr. Justice Stewart, expressing concern that the formalization of procedures may seriously undermine the values of the juvenile court because "a juvenile proceeding's whole purpose and mission is the very opposite of the mission and purpose of a prosecution in a criminal court." Id. at 79.

${ }^{130}$ See Wedemeyer \& Moore, The American Welfare System, in LAw of THE Poor 2, 12-13 (J. ten Broek ed. 1966).

140 Even during the troubled year 1964-65 at the University of Califorma at Berkeley, the chairman of the Faculty Committee on Student Conduct (a member of the law faculty with considerable expertise in matters of procedure) concluded that informal procedures were still appropriate, and acceptable, for 90 percent of the cases heard-all but the highly controversial political cases. His report noted that "the bulk of cases involves cheating or stealing or general disorderly conduct. The student admits the charges in all but insignificant detail and attempts to explain or justify. There is no need for pleading or charges or cross-examination."

141 See O'Neil, Private Universities and Public Law, 19 Buffalo L. Rev. 155 (1970). 
presumably neutral forum. At least there is little evidence that the conceded "judicialization" of many once informal relationships between benefactor and beneficiary has exacerbated tensions created by wholly different forces.

Second, there is a valid concern that insistence on strict procedural safeguards may rigidify the dispensation of benefits and thus undermine important interests of a whole class of present and potential beneficiaries. Chief Justice Burger expressed this anxiety in his Kelly dissent. While those now on the rolls may indeed be harder to get off the rolls, the natural bureaucratic response will be to make it much harder for future applicants to get on these rolls. ${ }^{142}$ Growing recognition of student rights may have caused some universities to scrutimize their admission policies more closely, although such surveillance has almost certainly been designed to spot applicants who may disrupt the campus rather than those who will demand formal adversary hearings when accused of disruption. And the predicted result would follow only to the extent the initial decision on eligibility remains unreviewable, a premise that is already in doubt. ${ }^{143}$

Moreover, even if better protection for those within the system does raise the barriers for those outside, it is far from clear that such a cost is excessive or unreasonable. Important differences between the respective sets of interests favor greater solicitude for the incumbent. There is a clear element of reliance within the system. The public housing tenant has given up his private apartment, the student has forgone opportumities to matriculate elsewhere, and the welfare recipient may have given away or put beyond his control assets that would initially have made him ineligible but would also have kept him alive if his application had been rejected. Thus if a preference has been expressed between insider and outsider in favor of the former and if some choice is inevitable, the choice has rightly been made.

There is a third concern about the extension of procedural rights. This tendency may well cause internal agency initiative to atrophy in vital areas. If left to its own devices, the argument runs, the administrative process would eventually do a better job than the

142397 U.S. at 279.

143 See Note, note 58 supra, at 1327-28. And see discussion in the text infra, at notes 202-08. 
courts, for administrators know both the needs of their beneficiaries and the resources of the system far better than do the courts. ${ }^{144}$ The argument finds a counterpart, again, in the Kelly case. The dissenters argued the Court should stay its hand, since the responsible agency was about to issue a ruling that would adequately meet the needs of all parties. The proposed HEW regulation was, in fact, more generous than the Court's mandate in certain respects. It assured that payments would continue until the statutory fair hearing was held and the fair hearing included certain safeguards not demanded by the Court. Yet as we have seen, the agency dragged its feet on promulgation of the rule for some months and seemed to be in no mood to take the critical step unless the courts compelled it. ${ }^{145}$ For the Court to have stayed its hand would thus have supported the status quo rather than stimulating agency initiative in fashioning new and especially appropriate procedures. In the student dismissal area, moreover, college and university administrators moved slowly enough in the reshaping of conduct rules and procedures even after the judicial mandate was clear. ${ }^{146}$ Before the courts began to speak, in the early 1960's, campus regulations remained pretty much as they had been at the turn of the century. Discipline at Grayson Kirk's Columbia varied little from that of Nicholas Murray Butler's time. ${ }^{147}$ Thus the record of recent experience belies any such optimism about the self-improving impulse of the administrative process. All too often, the only way to move

144 Compare, however, Professor Newman's view that "administrators (and investigating committees, grand juries, and in fact all lesser officials with jobs to do) have demonstrated ... that they are less trustworthy with respect to procedure than are judges." Newman, note 122 supra, at 230.

145 See Christensen, note 71 supra.

140 This conclusion emerges from a study conducted in the spring of 1970 by the author and three 1970 graduates (then third-year students) of the University of California Law School (Boalt Hall). The study surveyed student conduct rules at some twenty-two major umversities (half public aud half private, paired in eleven states). Rules and regulations were obtained for three sample years-1959$60,1965-66$, and 1969-70. Even at the large public universities, major reforms in procedural protections did not occur until late in the decade-suggesting that student protest may have been a more effective catalyst for change than litigatiou. For this and other conclusions from the survey, the author is particularly indebted to Mr. Ted W. Harris of the Class of 1970 for lis thorough and insightful work.

147 See, e.g., Van Alstyne, Procedural Due Process and State University Students, 10 U.C.L.A. L. REv. 368 (1963), reporting the rather surprising results of an earlier survey of disciplinary procedures. 
agencies toward adequate procedural safeguards for beneficiaries' rights is for the courts to push from behind.

Fourth, it is argued that the agency's discretion may be impaired and the confidentiality of some of its sources jeopardized by requiring an adversary hearing. If, as one court has already held, a nontenured professor is entitled to a hearing on the nonrenewal of his term contract, ${ }^{148}$ then academic judgment may be upset and confidentiality breached. The risks are real and grave, but not inevitable even in this most sensitive of areas. For if the administration (in the form of a dean or department chairman) gives constitutionally valid reasons for the failure to renew the contract-i.e., deficient teaching, meager evidence of creative research, or inadequate progress toward a higher degree-that should be the end of the matter. ${ }^{149}$ The right to be heard does not always encompass the right to know who made the initial evaluations on which the ultimate judgment was based. Nor need the department open all its files to the aggrieved junior member. The scope and character of the hearing must of course reflect common sense and vary with the special needs and circumstances of the parties. ${ }^{150}$ Evidence that must be disclosed when a student is expelled for cheating-or a faculty member suspended for plagiarism, for that matter-need not be exposed to public view when the dispute concerns a nonrenewal. Yet the essential right to know the reasons for an adverse determination and to argue in one's own behalf before the judgment becomes final is not crippled by such limitations.

Finally, there is the matter of expense. Hearings are costly, both in time and money. Lawyers are expensive, as are court reporters and stenographers. Administrative efficiency may be impaired by protracted hearings. Important questions may be kept in limbo interminably by formalities. Lawyers comprehend all this, but laymen do not. Thus the concern is altogether understandable, just as it is substantial. Yet in the determination of constitutional rights, the courts have repeatedly deemed such administrative concerns irrelevant. School integration cannot be postponed because it is likely

148 Roth v. Board of Regents, 310 F. Supp. 972 (W.D. Wis. 1970).

${ }^{149}$ See discussion of the Rotb decision, text infra, at notes 199-201.

${ }^{150} \mathrm{Cf}$. on the need to protect confidentiality of sources even against a fairly strong claim of disclosure, McCray v. Illinois, 386 U.S. 300 (1967). Comparable limitations could undoubtedly be fashioned for the administrative process where appropriate to meet particular governmental exigencies. 
to cause disorder. ${ }^{151}$ Adequate police protection cannot be denied a controversial speaker or an unpopular parade because providing it will be costly or inconvenient for the city. ${ }^{152}$ Similarly, a hearing cannot be withheld or even postponed simply because it may be expensive or disruptive. The agency must find ways to afford hearings within its budget and get its other work done at the same time. These are not irreconcilable goals for large bureaucratic organizations that already carry on myriad, complex, and often costly fnnctions.

C. CONTENT OF THE HEARING: HOW MUCH PROCESS IS DUE?

When a constitutional right to some form of hearing is recognized, the most difficult part of the analysis begins. What particular safeguards-of the dozens theoretically available to the administrative process-constitute due process in the specific instance? Which of these safeguards cannot be denied if the hearing is to be nueaningful? By what standards are these questions of implementation to be decided? There is surely no simple code that furnishes the answers. Every judge has his own sense of what "fairness" or "justice" includes in the realm of procedures, but there is no uniformity of judicial instinct. The question of defining or prescribing due process is-as Professors Sanford Kadish ${ }^{153}$ and Frank Newman ${ }^{154}$ have perceptively shown-as perplexing as it is fundamental.

In the Kelly case, the Supreme Court majority could agree that certain safeguards were requisite while others were dispensable. Thus the client faced with termination had a constitutional right to bring his own lawyer with him but not to have one appointed. The tribunal should be impartial, but no rigid rule of separation of functions would disqualify every member of the agency staff who had some prior involvement with the case. An opportunity to confront and cross-examine adverse witnesses was absolutely essential, yet the Constitution did not require a verbatim transcript of their answers. The seven-day notice that New York provided

151 Cooper v. Aaron, 358 U.S. 1 (1958).

152 Hurwitt v. City of Oakland, 247 F. Supp. 995 (N.D. Calif. 1965); Williams v. Wallace, 240 F. Supp. 100 (M.D. Ala. 1965).

153 Kadish, Methodology and Criteria in Due Process Adjudication-A Survey and Criticism, 66 YALE L.J. 319 (1957).

154 Newman, note 122 supra. 
under existing procedure adequately apprised beneficiaries of impending termination, "although there may be cases where fairness would require that a longer time be given."155

Thus from reading the Kelly decision we know a great deal about what the Justices believe to be the essential elements of due process in the particular circumstances. But we know virtually nothing-save possibly with regard to the right of confrontation ${ }^{165}$ -about the reasons why particular guarantees obtain at a given stage of the administrative process.

The lower courts have had to fend for themselves in shaping the contours of process that is due government beneficiaries. Within the past five years, for example, each of the following issues has been litigated in the context of state college student expulsion or dismissal: (1) How far in advance of the hearing must notice be given, and in what form? ${ }^{157}$ (2) Does the student have a right to be represented at the hearing by counsel-and does it make a difference whether the university appears by an attorney?158 (3) Must the hearing be public if the student requests it? If the university wishes a public hearing but the student desires it closed? ${ }^{150}$ (4) Does the student or his attorney have a right to examine adverse statements on which the charges are based? ${ }^{160}$ To cross-examine adverse witnesses at the hearing? ${ }^{161}$ (5) Must a verbatim transcript in detailed summary of the testimony be kept? ${ }^{162}$ (6) May the committee or hearing officer proceed in absentia if the student fails

155397 U.S. at 268.

156 Id. at $269-70$.

157 Compare Due v. Florida Agricultural \& Mechanical Univ., 283 F. Supp. 396 (N.D. Fla. 1963), with Scoggin v. Lincoln Univ., 291 F. Supp. 161 (W.D. Mo. 1968).

158 Compgre Barker v. Hardway, 233 F. Supp. 228 (S.D. W.Va. 1968), with French v. Bashful, 303 F. Supp. 1333 (E.D. La. 1969).

159 Compare Buttny v. Smiley, 281 F. Supp. 280 (D. Colo. 1968), with Moore v. Student Affairs Comm., 284 F. Supp. 725 (M.D. Ala. 1968).

160 See Estaban v. Central Mo. State College, 277 F. Supp. 649, 651 (W.D. Mo. 1967).

161 Compare Dixon v. Alabama State Bd. of Educ., 294 F.2d 150, 159 (5th Cir. 1961), with Estaban v. Central Mo. State College, 277 F. Supp. 649, 652 (W.D. Mo. 1967).

162 Compare Due v. Florida Agricultural \& Mechanical Univ., 283 F. Supp. 396, 403 (N.D. Fla. 1963), with Estaban v. Central Mo. State College, 277 F. Supp. 649, 652 (W.D. Mo. 1967). 
to appear after receiving timely notice? ${ }^{163}$ (7) Must the person who has the power to impose sanctions or penalties actually hear the case or study the transcript? ${ }^{164}$ (8) Must there be a complete separation of functions and a prohibition of ex parte communication between those who prosecute and those who decide? ${ }^{165}$ (9) Must the student have an opportunity to appeal internally from an adverse decision at the initial level? ${ }^{166}$ (10) May a student be suspended on an interim basis or must the hearing precede even a temporary change in status, and in what circumstances? ? $^{167}$

The wonder is not that so many specific safeguards have been sought but rather that in nearly all the ten enunerated areas the lower federal and state courts have divided sharply. Some have held there is a right to counsel in all cases, others that there is no such right of representation, and at least one other that the student may bring his lawyer whenever the university appears by counsel. Comparable divisions characterize most of the other areas, nraking it virtually impossible to give clear answers to university administrators who seek guidance in developing disciplinary codes consistent with due process. There is certainty only at the extremes. On the one hand, the student must be given formal notice of the specific charges. On the other hand, guilt need not be proved beyond a reasonable doubt or determined by a jury.

The task of prescribing due process thus remains at large. What guideposts might mark the path more clearly? ${ }^{168}$ First, we could

163 Compare Wright v. Texas Southern Univ., 392 F.2d 728 (5th Cir. 1968), with Marzette v. McPhee, 294 F. Supp. 562 (W.D. Wis. 1968).

164 See Estaban v. Central Mo. State College, 277 F. Supp. 649, 652 (W.D. Mo. 1967).

165 Compare Wasson v. Trowbridge, 382 F.2d 807, 813 (2d Cir. 1968), with Jones v. State Bd. of Educ., 279 F. Supp. 190, 202 (M.D. Tenn. 1968).

100 Compare Knight v. State Bd. of Educ., 200 F. Supp. 174 (M.D. Tenn. 1961), with Zanders v. Louisiana Stare Bd. of Educ., 281 F. Supp. 747, 761 (W.D. La. 1968).

107 Compare Jones v. State Bd. of Educ., 279 F. Supp. 190, 202 (M.D. Tenn. 1968), with Stricklin v. Regents, 297 F. Supp. 416, 420-21 (W.D. Wis. 1969).

168 British and Commonwealth courts have recently found it necessary to undertake a strikingly similar inquiry in student dismissal cases. The touchstone there has been "natural justice" rather than "due process"-a phrase of comparable breadth and imprecision. In University of Ceylon v. Fernando, 61 Ceylon New L. Rep. 505 (1960), it was held that in the absence of stated rules to be followed in dismissing a student for alleged cheating on an examination, principles of natural justice did entitle the student to "be adequately informed of the case he had to 
begin with a model of some sort-the criminal trial or the requirements of the Administrative Procedure Act-and then require the agency to justify any deviations from that model. Some years ago Professor Kadish suggested a formula for what he called "justification of the attenuated procedure": ${ }^{169}$

Whether it be determined that the impact is equivalent to or less than the consequences of a criminal conviction, a rational decision of whether the demands of due process allow any attenuation of traditional procedures must depend upon the case made in justification for the attenuation. The relation between the two factors would appear to be direct; the greater the severity of the impact of the determinations, the greater the degree of urgency and persuasiveness that must be shown. In the area of the federal employee loyalty program, for example, the Court has indicated its conviction that the impact of findings of disloyalty is similar to criminal sanctions. One might expect, therefore, the requirement of a relatively strong justification for iucreasing the hazard of misdeterminations.

This particular choice of model or norm may not be right for government benefit cases. Professor Newman has suggested the need for "awareness that due process sometimes should give people more rights than criminal proceedings ensure. The fact that pretrial discovery may be narrow in criminal cases, for example, hardly means that it should be no broader in hearings on license applications."170 For the same reason the Administrative Procedure Act, which already incorporates compromises between competing inter-

meet, and given an adequate opportunity of meeting it." The denial of crossexamination was held not to be a violation of natural justice in the absence of a tinuely request for confrontation.

For a much later and more elaborate inquiry into the relevant principles of natural justice, see R. v. Senate of the University of Aston, [2] 1969 All ER. 964 (Q.B.D. 1969). The Justices concluded that natural justice had been denied when the university proceeded to expel without a formal hearing of any sort-especially since the examiners had considered issues other than the student's academic performance in reaching their decision. Id. at 975 .

See also, for a less generous view of the scope of natural justice in student dismissal cases, King v. University of Saskatchewan, 68 W.W.R. 745 (Sup. Ct. of Canada 1969). The court held that faculty menibers could serve in the same case on both inferior and superior tribunals within the university.

169 Kadish, note 153 supra, at 352.

170 Newman, note 122 supra, at 220 . The criminal model may' also be inappropriate because of its enuphasis on the role of the jury and the value of judgment by peers. 
ests, should not be the norm. The question here is not whether further attenuation is justified, but whether any departures are warranted. This caution suggests a second approach. Rather than taking an existing model of procedure as the point of departure, one should start with a hypothetical proceeding in which all guarantees are fully enjoyed, and then require justification of any deviations from that ideal base. The hypothetical model would thus amalgamate the best of the criminal and civil procedure on the assumption that both could be practiced in a single forum. Exceptions or variations could then be authorized on a selective basis, reflecting particular governmental interests.

Certain obvious deviations from the ideal model would require no justification. No one seriously argues, for example, that a "grand jury" must "indict" the beneficiary before a hearing can occur, although the requirement of a prior hearing may serve some of the very same interests. It is not claimed that "guilt" must be proved according to the criminal standard, although it is vital to recognize that the agency or government bears the initial burden of proof on all disputed facts. In addition to these safeguards which are simply inappropriate to the administrative process, others might be positively harmful, or destructive of the flexibility and informality that should mark agency proceedings at their best. Thus the criminal or even civil trial rules of evidence are never invoked in agency hearings, and should not be. A complete separation of functions (of the sort essential to preserve judicial integrity) might undermine the agency's vital counseling function, preventing a senior professor, for example, from advising and informally reviewing the work of a junior nontenured colleague if he is later to sit in judgment on the younger man's case. Such departures as these require no justification beyond reference to the nature of administrative procedure.

A wholly different approach to the due process determination would be to start at the opposite end-assuming only the bare essentials of a hearing-and require the beneficiary or claimant to justify augmentation. The presumption, in other words, would be against representation by counsel, but the beneficiary could make a showing of special need for legal advice on the basis of the complexity of the case or his own inability to present or challenge the critical evidence, etc. But procedural safeguards should not be so jealously reserved or sparingly dispensed. Given the relative familiarity with 
the administrative process, it is certainly harder for the beneficiary in a single instance to show why he should have a particular protection then for the agency to demonstrate why he should not have it. Thus if there are any presumptions, they should run in the beneficiary's favor with the burden of rebuttal on the agency.

There is a third and middle ground that may best serve the interests of agency and beneficiary alike. A reviewing court should insist initially upon a rather high level of protection in all cases-including representation by counsel and probably appointed counsel for all indigents; ${ }^{171}$ opportunity for discovery and for cross-examination; preparation of a transcript or at least the making of a complete tape of the hearing; a public hearing; and so on. If the beneficiary feels stricter safeguards are essential, he can seek them and after an adverse decision can appeal the denial of them. The court will then examine the particular balance of interests and equities and decide-as courts have frequently done in the student dismissal cases -whether a higher standard should apply on an ad hoc basis. Conversely, if the agency feels special needs warrant dilution of the regular protections-a vital source of information would be jeopardized by disclosure, or a public hearing would be unmanageableit can make the exception and proceed subject to judicial review under the same standards. Experience with enough cases of this sort should generate a set of procedural standards sufficient to protect the interests of all parties.

\section{FULC JUDICIAL REVIEW: A VIABLE ALTERNATIVE TO THE ADVERSARY HEARING?}

When an agency fails to hold a full hearing and the matter comes before a reviewing court, it is sometimes suggested that the administrative default can be cured by de novo judicial review. ${ }^{172}$ It is true the court can certainly perform most or all of the adjudicative tasks as well as the agency-indeed, in some respects better, because the court has compulsory process, more. effective constraints against

171 Not only does the new regulation of the Department of Health, Education, and Welfare provide for counsel in fair hearings, see note 88 supra, but the Federal Trade Commission has ordered that counsel be made available to indigents appearing before the commission to answer charges. This is apparently the first federal regulatory agency to confer such a right in civil proceedings. N.Y. Times, Jan. 10, 1970 , p. 67, col. 4.

172 For the strongest such suggestion, see Jordan $\dot{ }$. American Eagle Fire Ins. Co., 169 F.2d 281 (D.C. Cir. 1948). 
contempt, better procedures for making records, and so on. But for the typical government beneficiary, judicial review must be a supplement and not a substitute for the administrative hearing to which he is entitled.

The court cannot cure the agency's dereliction for a variety of reasons. First, the costs of litigation are incalculably greater. Even with the aid of volunteer lawyers, few welfare recipients can afford to file lawsuits every time they are threatened with termination. Other beneficiaries, notably middle-class college students and public employees, must bear the entire costs, since they seldom qualify for legal aid. Second, there are often rather serious barriers to judicial review of withdrawal of government benefits, and a fortiori to initial demial of claims. Whatever vestiges remain of the "privilege" concept of public largesse emerge as rules of standing and justiciability when agency discretion in withholding or taking away a benefit is challenged in court. ${ }^{173}$ Third, there is of course nothing to challenge in court if the agency acts summarily and without explanation. Judicial review is possible only if there is some record either in the form of a hearing or at least a statement of reasons for the action. Fourth, the long delays created by typically overcrowded dockets make judicial review a meaningful alternative only for the beneficiary who can afford to wait. Thus the welfare recipient or public housing tenant is usually in no position to wait until his case comes to the top of the calendar in the ordinary course. There is of course, no guarantee that the administrative process acts more promptly. But if the agency must stay its hand until the question of eligibility has been determined within, there is at least a strong incentive for dispatch of a kind that finds no counterpart in the courts. Thus for many reasons court review provides no appropriate alternative to agency hearing.

Are there other alternatives? The agency does have a choice where a prior hearing is required. "Due process does not, of course, require two hearings," the Court recognized in Kelly. "If, for example, a state simply wishes to continue benefits until after a 'fair' hearing there will be no need for a preliminary hearing." 174 The matter of timing does afford the agency some option. But there is

173 Recent relaxations of the rules of standing have, of course, made judicial review more accessible for all plaintiffs, including those seeking to vindicate a claim to government largesse. See, e.g., Barlow v. Collins, 397 U.S. 159 (1970).

174 397 U.S. at 267 n. 14. 
no suggestion here or elsewhere that the basic functions and values of an adversary hearing can be served by any other procedure yet devised. In the absence of some hypothetical alternative model, it seems axiomatic that only a hearing can afford an aggrieved beneficiary a meaningful opportunity to be heard.

\section{The Framework Applied}

One task remains: To apply the abstract analysis to particular situations. Three phases in the dispensation of government benefits merit attention-the termination or dismissal, the nonrenewal, and the rejection of an initial application. One preliminary matter must, however, be disposed of: the cases involving licenses or admission to professional or occupational practice.

\section{A. THE LICENSING CASES: SUI GENERIS}

Read broadly, the cases involving the denial or granting of professional and other licenses would resolve all other problems. The Supreme Court long ago held that an accountant could not be denied admission to practice before the Board of Tax Appeals without a hearing. ${ }^{175}$ More recently the Court took a similar view of New York's rejection of an application for admission to the bar based upon unfavorable character references. ${ }^{176}$ It is assumed a fortiori that the withdrawal or cancellation of a license or permit to practice an occupation or profession requires some formal hearing. ${ }^{177}$ If the licensing cases were applicable in other contexts, there would be no need for further inquiry.

The licensing cases are not, however, adequate precedent for the government benefits area. Fundamentally, a license is much more a form of regulation than a dispensation of government largesse. Were there no regulation at all, however essential that regulation might be, any person who wished could undertake the licensed activity at his own risk. The granting of the license thus involves a determination of competence and qualification within the scope of regulatory power, a selection of some among all those who seek

175 Goldsmith v. Board of Tax Appeals, 270 U.S. 117, 123-24 (1926).

176 Willner v. Committee on Character and Fitness, 373 U.S. 96, 103-06 (1963).

Cf. Hornsby v. Allen, 326 F.2d 605 (5th Cir. 1964).

${ }_{177}$ See generally 1 Davis, note 10 supra, at $\$ 7.18$. 
access to the regulated field or activity. In this sense the denial of a license represents a limitation or restraint upon the theoretical liberty of the citizen in an unregulated society.

Moreover, the rejection of an application automatically implies some lack of competence, moral character, or responsibility. This inference arises because in most regulated sectors-save possibly for broadcasting by radio and television-there is no quantitative reason for denying any new applicant a chance to enter the field. Whether he can practice profitably is his own business. Whether there are too many lawyers or doctors or automobile drivers or liquor dealers is no business of the licensing agency, whose sole concern should be one of quality: to protect the public, and sometimes other members of the regulated sector, from incompetent or inferior practitioners.

The denial of most applications for government benefits imports no such stigma. The number of opportunities available at any given time is limited, even perhaps in the welfare area. Public housing projects typically have many more applicants than vacancies. ${ }^{178}$ State colleges and universities can admit only a fraction of prospective matriculants. Government agencies can hire only a limited number of employees and, except in the Post Office and nienial lines of work, applications exceed openings. Thus a rejection or denial may reflect a judgment about competence or character. But that is not, as with the denial of a license, the inevitable implication of adverse action.

For both reasons, then, the case of the licensee or prospective licensee is rather different from that of the typical government beneficiary. Though the Supreme Court has never sought to distinguish the two classes of cases-indeed, in Kelly it rather casually assimilated them-the distinction seems clear enough to demand a separate analysis. The insistence upon granting a hearing to the licensee or applicant may thus be persuasive by analogy but hardly dispositive of the issues now before us.

\section{B. DISCHARGE, DISMISSAL, TERMINATION, EXPULSION, AND EVICTION}

I begin with the easiest of the three phases in the dispensation of government benefits. In niany programs, the matter is already set-

${ }^{178}$ See the figures on the ratio of applicants to vacancies in New York Cityabout 10:1 in recent years. Project on Soclal Welfare Latv, Housing for the PoOR: Rights AND Remedies 172, n. 41 (1967). 
tled. For welfare recipients, Kelly clearly established both the right to a full hearing and the right to an adversary prior hearing. For public housing tenants, comparable rights have been recognized by administrative regulation, reinforced by one Supreme Court decision, ${ }^{179}$ and more recently given constitutional underpinning by several lower federal courts. ${ }^{180}$

The state college or university student, too, clearly has a constitutional right to a hearing when he is expelled or suspended for a substantial period. ${ }^{181}$ The only issue that remains is one of timing. Prior to Kelly the lower federal courts divided on the question whether a college could suspend the student first and then hold the hearing later, the controversial practice of interim suspension. ${ }^{182}$ In Kelly the Supreme Court said nothing about students in distinguishing other types of beneficiaries. Yet equities similar to those of the welfare client could surely be invoked in the case of a student summarily suspended on the eve of examinations or at a time when he is draft-vulnerable or in a way that will forfeit a fellowship. Whenever such special circumstances are present, the case for a prior hearing seems compelling. Even when no special equities are present, the university should bear the burden of showing why it cannot hold even a preliminary hearing before imposing a suspension. ${ }^{183}$

This leaves public employment as the area in which, ironically, the question of the right to a hearing was earliest litigated but last to be resolved. A casual comment in Kelly might suggest otherwise: "Relevant constitutional restraints," observed Mr. Justice Brennan, "apply as much to the withdrawal of public assistance as to ... discharge from public employment." 184 The citation supporting the

179 Thorpe v. Housing Authority, 393 U.S. 268 (1969).

180 Escalera v. New York City Housing Auth., 425 F.2d 853 (2d Cir. 1970); Ruffin v. Housing Auth., 301 F. Supp. 251 (E.D. La. 1969).

181 Dixon v. Alabama State Bd. of Educ., 294 F.2d 150 (5th Cir. 1961).

182 Compare Jones v. State Bd. of Educ., 279 F. Supp. 190, 202 (M.D. Tenn. 1968), with Stricklin v. Regents, 297 F. Supp. 416, 420-21 (W.D. Wis. 1969), appeal dismissed, 420 F.2d 1257 (7th Cir. 1970).

183 Indeed, in one of the very earliest student dismissal cases of the 1960's, it was simply assumed that a prior hearing would be granted if the right to a hearing was recognized at all. Knight v. State Bd. of Educ., 200 F. Supp. 174, 178 (M.D. Tenn. 1961) (due process required "an opportunity to present [the students'] side of the case before such drastic disciplinary action was invoked by the university authorities").

184397 U.S. at 262. 
reference was to Slochower v. Board of Higher Education, ${ }^{185}$ a 1956 decision involving a tenured professor at Brooklyn College who had been summarily dismissed for invoking the privilege of the Fifth Amendment before a congressional investigating committee. A regulation of the board made discharge mandatory and automatic under such circumstances. The Court held that a claim of constitutional right could not be made the sole basis for summary discharge of a public employee. At the close of the opinion, Mr. Justice Clark did say something about a hearing: ${ }^{186}$

The State has broad powers in the selection and discharge of its employees, and it may be that proper inquiry would show Slochower's continued employment to be inconsistent with a real interest of the State. But there has been no such inquiry here. We hold that the summary dismissal of appellant violates due process of law.

This statement, while surely relevant, is very far from establishing a government employee's right to a hearing on dismissal. That is clear both from the context and from later decisions. The Court in Slocbower really said no more than that the ground on which the dismissal was based-resort to a constitutional privilege not to incriminate one's self-clearly would not support so serious a sanction. The only way in which the state could use Slochower's conduct as the basis for dismissal was by establishing a relationship between that conduct and some valid interest of the state or the university-for example, by showing that he had perjured himself or been contemptuous of the committee. Such a nexus could be determined only by a hearing. Thus a hearing would have to be held, not before Slochower could be dismissed at all, but before he could be dismissed for a constitutionally protected act.

Later cases support this limited view of Slochower. The Court has gone back and forth on the matter of a public employee's right to a hearing, coming very close to recognizing such a right but avoiding the constitutional question in Greene v. McElroy, ${ }^{187}$ then backing away again in Cafeteria and Restaurant Workers Union v. McElroy. ${ }^{188}$ (The latter case established the balancing test used by the Court in Kelly, but ultimately denied the request for a hearing on cancellation of a security clearance.) One important milepost along

185350 U.S. 551 (1956).

186 ld. at 559.
187360 U.S. 474 (1959).

188367 U.S. 886 (1961). 
the way is the 1959 decision in Vitarelli $v$. Seaton. ${ }^{180}$ There the Court held that a public employee is entitled to a hearing if agency procedures confer such a right. The agency cannot play fast and loose with its own rules, adhering to them when it wishes but bypassing them when it does not. The basic constitutional question was not in focus. But the Court simply assumed that Vitarelli (a professional employee of the Department of the Interior) "could have been summarily discharged ... at any time without the giving of a reason." ${ }^{190}$ Later, the Court observed that neither an act of Congress nor an executive order (dealing with internal security matters) "alter[ed] the power of the Secretary to discharge summarily an employee in petitioner's status, without the giving of any reason."101 The problem of the case was that the Secretary "gratuitously decided to give a reason" and because the reason given was national security, backed himself into a procedural web foreclosing summary action.

Slocbower and Vitarelli, taken together, suggest only that when the sole reason given for a dismissal is either a constitutionally invalid one or one that requires, by statute or regulation, compliance with specific procedures, there is a right to a hearing. In both cases, moreover, the stated basis of the adverse judgment bore so heavily on the integrity or the loyalty of the employee as to create a "badge of infamy," an implication so damaging that only a full hearing could vindicate the individual's interest in reputation and make it possible for him to obtain employment in the private sector.

Absent these special equities, the public employee's claim to a hearing rests on shaky precedent. Many Supreme Court decisions have reinforced substantive rights of government workers: not to be discharged for criticizing the policies of the agency or superior officials; ${ }^{102}$ not to be required to sign a loyalty oath that infringes freedom of expression; ${ }^{193}$ not to be compelled to disclose constitutionally protected affiliations, ${ }^{104}$ etc. But nothing has been said about the right to a hearing since the Cafeteria Workers case, in which a hearing had been denied for security reasons and the action was sustained by a sharply divided Court. Incredible as it may seem, only one

189359 U.S. 535 (1959).

$100 \mathrm{ld}$. at 539.

101 lbid.

192 Pickering v. Bd. of Educ., 391 U.S. 563 (1968).

103 Elfbrandt v. Russell, 384 U.S. 11 (1966).

194 Shelton v. Tucker, 364 U.S. 479 (1960). 
lower federal court decision ${ }^{195}$ appears to recognize unequivocally a constitutional right to be heard before employment is terminated, and even that judgment masquerades as generous construction of agency regulations.

Long before Kelly, the courts had accorded government workers a host of substantive rights that could be vindicated only through adversary hearings, the requirement of specific charges, and an opportunity to confront and cross-examine accusers. ${ }^{196}$ Moreover, the disparity in treatment between government employees and other beneficiaries seems inexplicable. Being fired from a government job is at least as serious a sanction as being evicted from a housing project or being suspended from college. Nor are there unique interests attending the government's function as employer that find no parallels in the responsibilities of landlord, educator, and benefactor. There may, of course, be special problems in particular cases. Claims to confidentiality of sources may well be stronger in security discharge proceedings than in eviction or expulsion cases. But these interests can surely be respected without denying generally the right to an adversary hearing. And unless special circumstances intervene, the hearing should occur prior to the effective date of the discharge for all the reasons already discussed.

\section{NONRENEWALS OF GOVERNMENT BENEFITS}

The distinction between a termination and a nonrenewal is not always easy to define. Many benefits are technically granted for only a limited term. But the presumption of continuing eligibility is so strong that a refusal to renew or extend the relationship is properly treated as a termination. A student enrolls for only a year at a time. But if a freshman is denied, for nonacademic reasons, a chance to enroll for the sophomore year, he is really being terminated rather than denied a renewal of his student status. ${ }^{197} \mathrm{~A}$ public housing tenant, similarly, may have a lease for a year-or even on a month-tomonth basis-but a refusal to renew or extend the lease is tantamount to an eviction and so treated by the courts. ${ }^{108}$

\footnotetext{
105 Olson v. Regents, 301 F. Supp. 1356 (D. Minn. 1969).

106 See generally Linde, note 94 supra; Van Alstyne, note 10 supra.

197 Saunders v. Virginia Polytechnic Inst., 417 F.2d 1127 (4th Cir. 1969).

108 In Thorpe v. Housing Authority, 393 U.S. 268 (1969), for example, the Court treated as an "eviction" the exercise of the housing authority's option under the lease to terminate tenancy by giving notice at least fifteen days before the end
} 
The paradigm case of true nonrenewal is, of course, the nontenure academic appointment. There is a mild presumption that the instructor or assistant professor who does satisfactory teaching and makes adequate progress toward a higher degree will be continued, at least until the tenure decision is made. But there is nothing automatic about this relationship as about the others just cited. Historically, therefore, it has simply been assumed that a nontenure employee could be dropped at the end of a term without the giving of any reasons and with no recourse. Within recent months, however, a pair of federal district court decisions have dramatically altered this easy assumption on which academic and other public administrators have operated.

In Roth v. Board of Regents, ${ }^{199}$ Judge Doyle of the Western District of $W$ isconsin held that a nontenure assistant professor may not be denied renewal without a statement of the reasons for the action and an opportunity at least to be heard in his own behalf. Starting with the assumption that improper reasons did not in fact underlie the action before him, Judge Doyle nonetheless concluded that the enforcement of substantive safeguards to which a public employee is now entitled would require a hearing in nonrenewal cases as much as in dismissals or discharges of tenured faculty and workers covered by civil service. For the failure to renew without giving any reasons could as well mask constitutionally improper reasons as reflect a constitutionally valid judgment about professional achievement and progress.

The decision is far less drastic than might at first appear. It does not hold that a full adversary hearing must be held on every nonrenewal, or that confidential documents must be disclosed: ${ }^{200}$

The burden of going forward and the burden of proof rests with the professor. Only if he makes a reasonable showing that the stated reasons are wholly inappropriate as a basis for decision or that they are wholly without basis in fact would the

of any monthly term. Such action was an eviction rather than a nonrenewal because the lease also entitled the tenant to auromatic renewal for successive monthly terms unless the family composition or income were altered or specific terms of the lease violated.

199310 F. Supp. 972 (W.D. Wis. 1970). See also the companion case, Gouge v. Joint School Dist. No. 1, 310 F. Supp. 984 (W.D. Wis. 1970), extending similar procedural protections to public school teachers.

200310 F. Supp. at 980. 
university administration become obliged to show that the stated reasons are not inappropriate or that they have a basis in fact.

The opinion does not say how precise the stated reasons must be to shift the burden of proof. If explanations like "unsatisfactory teaching" or "limited evidence of distinguished scholarship" would suffice, the duty placed upon the administration by the Roth decision would be rather slight. The possibility remains, moreover, that a decision resting in fact on one ground (i.e., controversial political activities) may be justified for the record on another (i.e., lack of scholarly output), since the performance of few junior faculty members is academically or pedagogically impeccable. Nor does the decision insulate against largely ad bominem judgments reflecting the personal likes and dislikes of elder colleagues. Nonetheless, Judge Doyle has clearly taken a bold step toward lifting the shroud of secrecy that has long surrounded the nonrenewal of probationary appointments. The case seriously undermines the belief that a nontenure employee can be summarily terminated by giving no reasons and may obtain judicial review only if the agency gratuitiously gives an invalid or implausible reason.

Meantwhile, parallel efforts are being made to ensure these same safeguards. Committee A of the American Association of University Professors recently proposed a new set of procedures to guide renewal decisions. The statement recommends, inter alia, that a junior teacher should be entitled to notice in writing of the reasons for a decision not to renew his appointment, and should be able to seek review by a "decision-malking body." That body should have authority to request reconsideration by the appropriate faculty committee when it concludes that insufficient deliberation was initially given the matter. ${ }^{201}$

The solution to the nonrenewal problem lies in recognizing its intermediate character in the range of administrative actions and in devising commensurate procedures. The decision not to extend a contract or appointment for a further term is less drastic than a discharge or dismissal from a continuing or tenured position, but more drastic than the typical decision not to grant the appointment ini-

201 The new guidelines were first announced in Chronicle of Higher Educ., April 13, 1970, p. 4, cols. 3-5. See also Report of Committee A, 1969-70, 56 A.A.U.P. BuLl. 153, 167 (1970). 
tially. The Rotb decision and the Committee A proposals attempt to reflect precisely that fact by fashioning a hearing procedure that assures adequate notice of the action and its basic rationale and which affords a chance to argue against the decision and its underpinning. Although no cross-examination or disclosure of confidential files is contemplated, at least at the outset, administrators accustomed to announcing nonrenewals without any explanation may find the new requirements burdensome and annoying. Yet presumably they can learn to live with these new rules, designed as they are to ensure fundamental fairness at the threshold of a young man's career.

\section{REJECTION OR DENIAL OF INITIAL APPLICATIONS}

We come at length to what may be the hardest case of all, the one on which existing law is least helpful. There are easy situations at the two extremes. On the one end, the licensing cases in which the Supreme Court has twice unequivocally held there is a constitutional right to a hearing when the applicant meets all the formally stated criteria for admission. ${ }^{202}$ At the other extreme, no one supposes there is a right to be heard when one candidate for a prize scholarship is chosen over many others, or when the President fails to nominate to a diplomatic post a person whose friends have eagerly recommended him. The hard cases lie across the broad middle range. The matter is not quite so simple as the district judge thought in the Toledo public housing case holding, after Kelly, that "those seeking to be declared eligible for public benefits may not be declared ineligible without the opportunity to have an evidentiary hearing." 203

Nor is the issue as clear the other way as it seemed to the welfare clients' attorneys in Kelly, who urged the Court to respect the "well-founded and established distinction between initial denial and revocation of statutory rights, entitlements or privileges." ${ }^{204}$ In fact, a hearing may be appropriate to some kinds of rejections and denials but inappropriate to others. What is needed is a set of standards to

202 Willner v. Committee on Character and Firness, 373 U.S. 96, 103-06 (1963); Goldsmith v. Board of Tax Appeals, 270 U.S. 117, 123-24 (1926).

203 Davis v. Toledo Metropohtan Housing Auth., 311 F. Supp. 795, 797 (N.D. Ohio 1970).

204 Brief in Reply to the United States as Amicus Curiae, Goldberg v. Kelly, 397 U.S. 254 (1970), at 6. Cf. Note, note 58 supra, at 1327-28. 
guide the particular judgment. The following questions suggest a framework.

1. Effect of rejection upon the applicant. At least two sorts of consequences flowing from a denial or rejection may warrant some sort of hearing, the one to reputation, the other to subsistence. The license cases point up the importance of holding a hearing when the rejection creates an automatic inference damaging to the applicant's reputation (for competence, for moral character, for loyalty).$^{205}$ The inference arises either where such licenses are granted pro forma, or where the particular applicant clearly meets every criterion except the one that centrally involves his reputation or standing. An equally compelling case can be made for challenging the inference generated by denial of a security clearance or even perhaps the rejection of an employment application for a highly sensitive job.

Subsistence or survival is an individual interest meriting at least comparable solicitude. Generally, it is true the incumbent welfare beneficiary or tenant has a greater claim to be heard than the suppliant. But this is not always the case. The evicted tenant may well be able to live with relatives while his case is being resolved, while the applicant may have come to the gates only because all other sources of shelter have been exhausted. The seeker of welfare may sometimes be even more destitute than the receiver and thus in greater need of a prompt and equitable resolution of his claim. Even large and bureaucratic agencies should be able to examine briefly at the threshold the circumstances of the initial applicant, and in deserving cases to grant a prompt hearing or extend a form of emergency aid pending resolution.

2. Nature of the decision-making process. The availability of a hearing at the application stage should also vary with the nature of the particular decision. Many judgments about eligibility are too simple and obvious to warrant a hearing, as where a claimant aged sixty-two is rejected for social security or retirement benefits that do not commence until age sixty-five. Others may reflect simply the application to uncontested facts of general policies or rules. These do not come within the "adjudicative" area at all. At the other extreme, some eligibility decisions may be so complex or may necessarily involve such vast discretion-high-level administrative ap-

205 E.g., Heckler v. Shepard, 243 F. Supp. 841, 847-52 (D. Idaho 1965). 
pointments, awarding of prizes, fellowships, and the like-that no readily ascertainable standards could be brought to bear in reviewing the rejection. Between the easy cases lie many in which the process is moderately complex or involves a measure of discretion exercised within broad guidelines or regulations. For these cases a hearing would not be inappropriate or unmanageable. The ultimate decision whether to grant it must depend upon the degree of complexity of discretion, tempered by the several other factors considered here. ${ }^{206}$

3. Relationship of bearing to substantive interests. Sometimes a hearing will be deemed essential even though neither of the foregoing elements is present, simply to vindicate vital substantive interests of the class from which the particular applicant comes. If one black person is rejected for a government job, that fact does not create a justiciable claim by itself. But if several blacks are rejected and there is reason to believe less qualified whites are being hired, a hearing may be essential simply to establish whether or not the agency is practicing subtle racial discrimination and to prevent future bias.

For just this reason one court has implied that an applicant for public employment may not be rejected for refusing to sign a loyalty oath without a chance to explain his reasons for refusing. The court concluded that the basic principle of pertinent Supreme Court loyalty-security decisions simply could not be vindicated without an opportunity for the arguably loyal nonsigner to be heard. ${ }^{207}$

4. Relationship of bearing to the administrative process and agency performance. For similar reasons a court may occasionally require an agency to articulate its standards for acceptance and rejection of applicants. ${ }^{208}$ The agency may take the hint and issue regulations on its own. But if it fails to do so, leaving prospective applicants in the dark about the criteria actually employed or the way in which conduct may be shaped to gain or retain eligibility,

206 For two recent illustrations of situations in which a hearing has been required on denial of an initial application, see Healy v. James, $311 \mathrm{~F}$. Supp. 1275, 1282 (D. Conn. 1970), involving eligibility of a controversial political group for recognition as a campus student organization, and Stacy v. Williams, 306 F. Supp., 963 (N.D. Miss. 1969), involving applications of controversial speakers for access to college and university campus forums.

207 Heckler v. Shepard, 243 F. Supp. 841, 847-52 (D. Idaho 1965).

208 E.g., Holmes v. New York City Housing Auth, 398 F.2d 262 (2d Cir. 1968), in which the court of appeals strongly urged the Housing Authority to publish and define the criteria used in determining eligibility for admission to projects. 
hearings on particular cases-chosen almost at random-may be the only way to force the agency to explain publicly how it manages the intake process. It may also be the only way in which other branches of government-notably the courts called upon to review agency decisions and the legislature asked to appropriate funds for its support-will be able to judge an important dimension of administrative performance. The equities of the individual applicant or even of the class from which he comes are relatively unimportant under this rubric. The essential factor is the willingness and capacity of the agency to keep the public apprised of its standards.

This discussion at least suggests the error of confining procedural safeguards at the initial stage to the licensing cases. There are few government benefit programs, perhaps none, in which an agency should not occasionally be required to explain and justify a rejection, either because the equities of a particular case are compelling or because agency responsibility can be assured only in this way. The Kelly decision neither affirms nor denies such a principle. Yet much of what the Court said about the plight of the beneficiary who is forced off the welfare rolls logically applies to the welfare claimant who is lept off the rolls for equally invalid or erroneous reasons. The case in which the Court will have to consider the extension of its logic may not be far in the future.

\section{Conclusion}

Is the right to a hearing worth the quest, after all? How substantial a guarantor of individual rights is procedural due process? Professor Joel Handler has wisely warned that assimilation of government benefit dispensing procedures to those employed in regulatory and licensing contexts may be an unreal goal, not because it cannot be attained, but because it will not necessarily produce major reform. The range of discretion in administration of most government benefit programs is so vast, so far beyond the reach of reviewing courts, that judicialization of procedure may reach only the highest level and most visible agency actions. Thus Professor Handler cautions: ${ }^{209}$

The experience of administration of business regulation and the peculiar problems of welfare administration cast doubt on the benefits to be gained from a program of rights. Its lack

209 Handler, Controlling Official Behavior in Welfare Administration, in Law OF THE POOR 155, 176 (J. ten.Broek ed. 1966). 
of utility in helping to fulfill the broader legislative goals-the rehabilitation of people-changing aspects of welfare programs -is manifest.

Yet it may be premature to judge the efficacy of quasi-judicial procedures in the government benefits context until we have more of them. The safeguards actually available to the beneficiary are still so far behind not only the criminal process but the business-regulatory context as well that major progress would be required even to establish a basis of comparison. Perhaps welfare beneficiaries and public housing tenants will not be greatly helped by knowing why they are being terminated or evicted. The agency will often talke its course anyway, undeterred by the annoying demand of formalities. But the history and the essential premises of due process are more hopeful. Strict adherence to fair procedures is at least worth a try. ${ }^{210}$

210 There is a final and perplexing question beyond the scope of this discussion but unavoidable in any complete analysis: How far can case-by-case constitutional adjudication really ensure the basic values claimed for due process? In a recent letter to the author, Professor Hans Linde cautions on this point: "I do nor believe that the solution to the problems of fair administration of mass benefits can be found in the due process clause but only in legislative reforms that minimize the need for factual determinations and discretionary judgments. This does not do away with the need for deciding due process cases in the form in which they now arise. But ... due process analysis cannot itself cope with the problems; it can only demonstrate, and hasten, the need for legislative restructuring of the programs." 